\section{Pacific Northwest}

National Laboratory

Operated by Battelle for the

U.S. Department of Energy

\title{
Preconceptual Design Description for Caustic Recycle Facility
}

\author{
G. J. Sevigny \\ A. P. Poloski \\ M. S. Fountain \\ D. E. Kurath
}

April 2008

Prepared for the U.S. Department of Energy/

Office of Environmental Management

under Contract DE-AC05-76RL01830 


\title{
Preconceptual Design Description for Caustic Recycle Facility
}

\author{
G. J. Sevigny \\ A. P. Poloski \\ M. S. Fountain \\ D. E. Kurath
}

April 2008

Prepared for the U.S. Department of Energy/

Office of Environmental Management

under Contract DE-AC05-76RL01830

Pacific Northwest National Laboratory

Richland, Washington 99352 


\section{Summary}

The U.S. Department of Energy plans to vitrify both high-level and low-activity waste at the Hanford Site in southeastern Washington State. One aspect of the planning includes a need for a caustic recycle process to separate sodium hydroxide for recycle. Sodium is already a major limitation to the wasteoxide loading in the low-activity waste glass to be vitrified at the Waste Treatment Plant (WTP), and additional sodium hydroxide will be added to remove aluminum and to control precipitation in the process equipment. Aluminum is being removed from the high level sludge to reduce the number of high level waste canisters produced. A sodium recycle process would reduce the volume of low-activity waste glass produced and minimize the need to purchase new sodium hydroxide, so there is a renewed interest in investigating sodium recycle.

This document describes an electrochemical facility for recycling sodium for the WTP. Overall, the facility consists of a small $\left(<10,000 \mathrm{ft}^{2}\right)$ canyon-type building with minimal shielding. The facility would be connected to the WTP via spare nozzles in the WTP pipe trench and would be classified as a Category 2 facility based on the inventory of radionuclides. The facility has waste receipt and lag storage tanks to support the process equipment. The process requires a large DC electrical supply system and cooling system for the electrochemical process in addition to the 28 electrochemical modules that contain 40 cells each. The process equipment maintenance is planned to be contact maintenance, but some localized and supplemental shielding will be required.

The preliminary design of a Caustic Recycle System is based on an electrochemical process using sodium super ion conductor (NaSICON) ceramics. The process is being demonstrated by Ceramatec and Pacific Northwest National Laboratory on a small scale with simulated and radioactive waste material. A preliminary design for a facility that could support the WTP at the Hanford Site is described in this report with the capability to recover 23,000 MT of sodium over a 25-year operating life. This description includes design requirements, configuration of the process building, the electrochemical process system, subsystems, and major components. The general operations in the facility are also described.

Appendix A contains a cost study summary, and Appendix B includes a flowsheet, an equipment list, and information about electrical loads. Appendix C discusses needs for technology development, and Appendix D shows examples of various kinds of equipment involved. 



\section{Acronyms}

\begin{tabular}{|c|c|}
\hline ALARA & as low as reasonably achievable \\
\hline ASHRAE & American Society of Heating, Refrigeration and Air Conditioning Engineers \\
\hline CRS & Caustic Recycle System \\
\hline CXP & Cesium ion exchange permeate \\
\hline $\mathrm{EC}$ & electrochemical \\
\hline ECR & Electrochemical Reactor \\
\hline ECT & Electrochemical Caustic Tank \\
\hline EPDM & ethylene-propylene-diene monomer \\
\hline EFT & Electrochemical Feed Tank \\
\hline ERBT & Electrochemical Return Buffer Tank \\
\hline ERT & Electrochemical Receipt Tank \\
\hline FFTF & Fast flux Test Facility \\
\hline HEPA & high-efficiency particulate air (filter) \\
\hline HLW & high-level waste \\
\hline ILAW & immobilized low-activity waste \\
\hline INEL & Idaho National Engineering Laboratory \\
\hline LAW & low-activity waste \\
\hline MT & metric tons \\
\hline NaSICON & Na super ionic conductor \\
\hline NPT & $\mathrm{NaOH}$ Product Tank \\
\hline PEEK & polyether-ether-ketone \\
\hline PNNL & Pacific Northwest National Laboratory \\
\hline PUREX & plutonium uranium extraction \\
\hline SBS & Submerged Bed Scrubber \\
\hline TDD & Task Description Document \\
\hline WTP & Waste Treatment Plant \\
\hline
\end{tabular}





\section{Acknowledgements}

This design relied strongly on the elicitation of information and informed judgment from knowledgeable Bechtel National Inc., Ceramatec, and Pacific Northwest National Laboratory staff. Although this list is incomplete, the authors would like to acknowledge the following for their participation: Billie Mauss, Shekar Bologapal, Langdon Holton, and Phil Brackenbury. 



\section{Table of Contents}

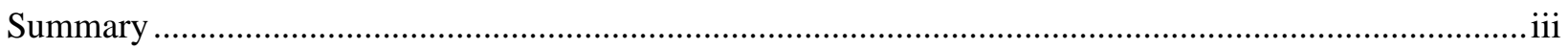

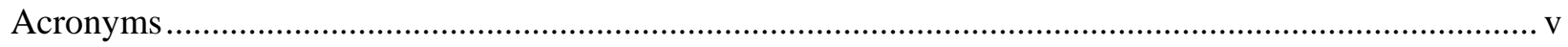

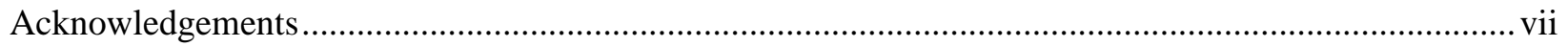

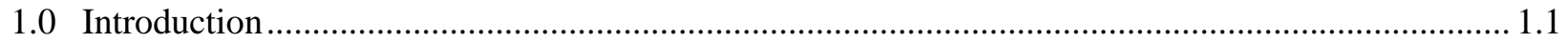

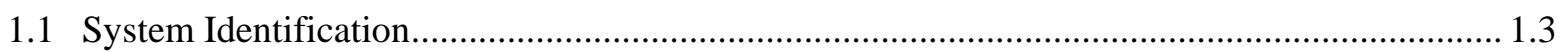

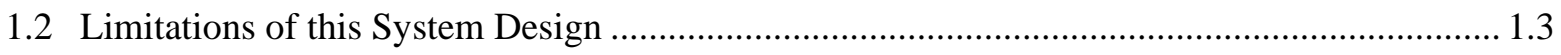

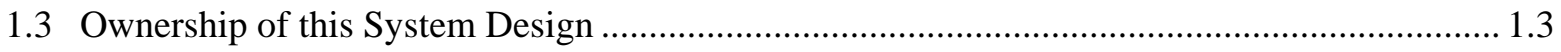

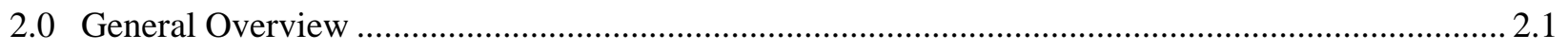

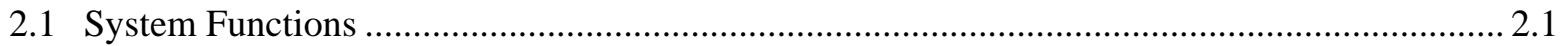

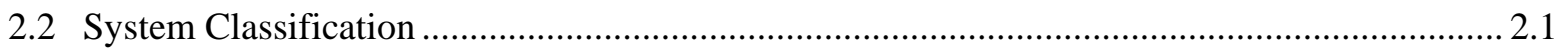

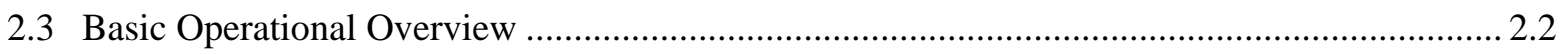

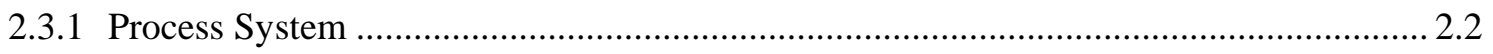

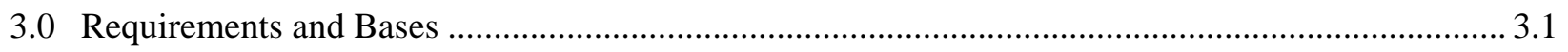

3.1 System Functional Requirements and WTP Assumptions ...................................................... 3.1

3.2 Subsystem and Major Components Requirements............................................................ 3.2

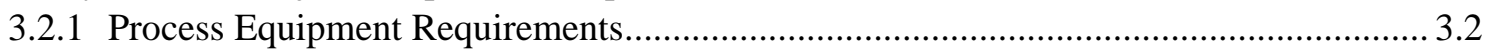

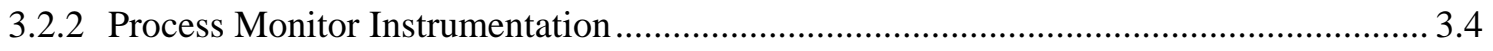

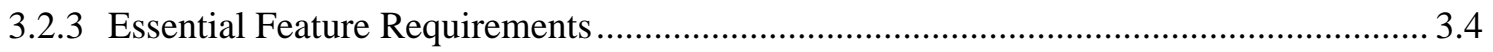

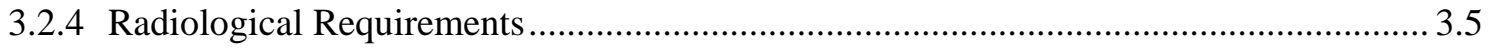

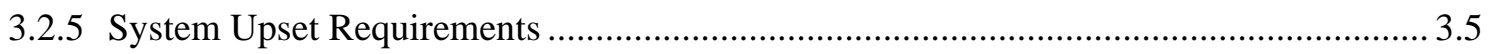

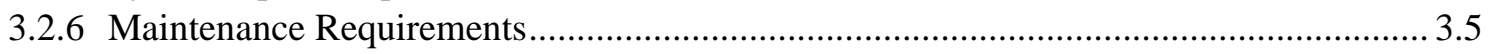

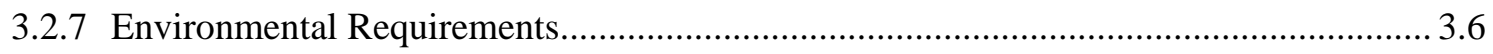

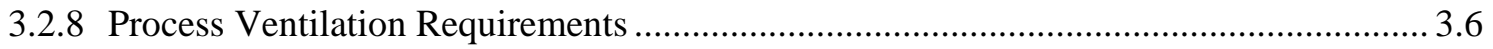

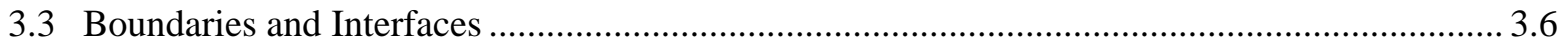

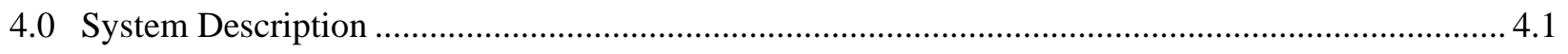

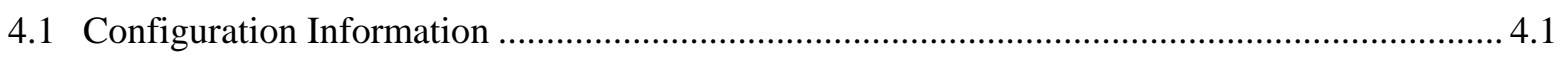

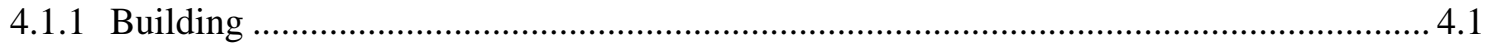

4.2 Description of System, Subsystems, and Major Components................................................. 4.2

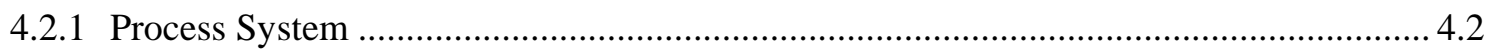

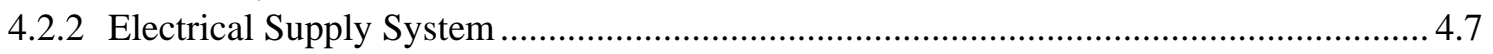

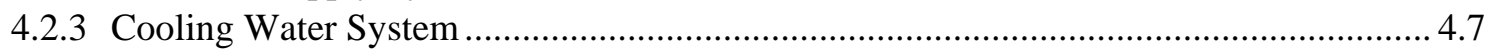

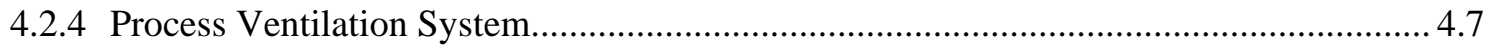

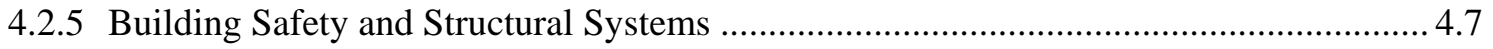

4.2.6 Building Heating and Ventilation ............................................................................. 4.7 


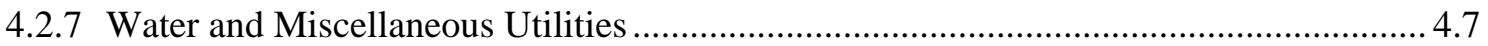

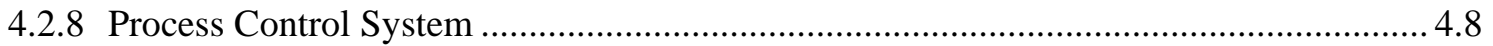

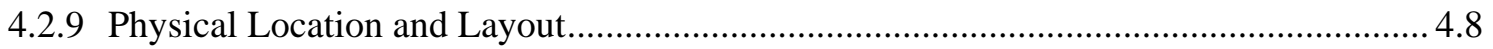

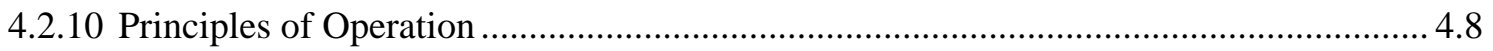

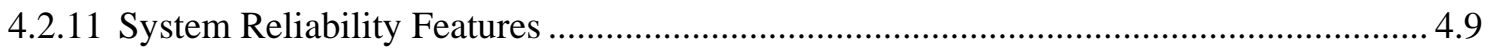

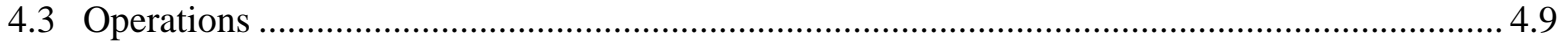

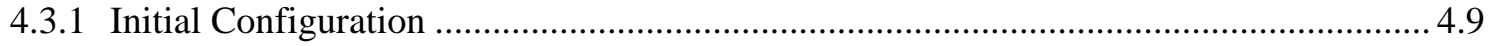

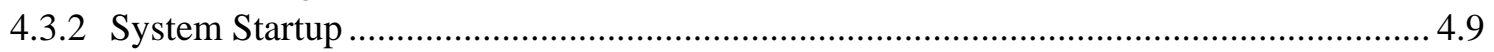

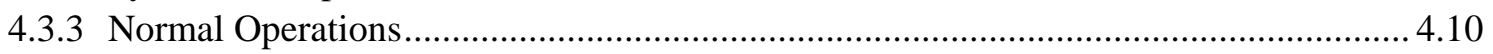

4.3.4 Off-Normal Operations (System Upsets) ...................................................................... 4.10

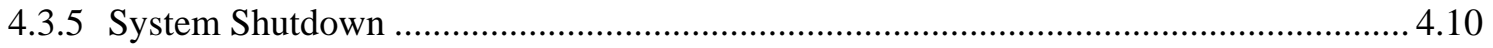

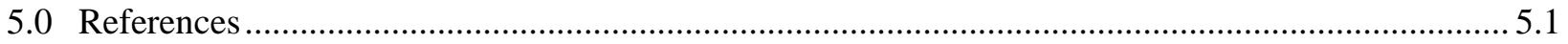

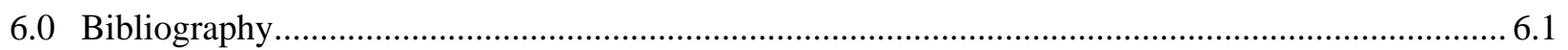

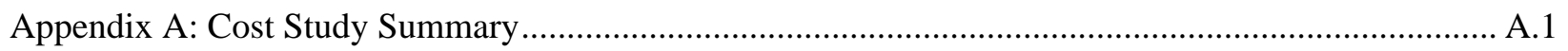

Appendix B: System Sketches, Equipment List, and Electrical Loads..................................................1

Appendix C: Technology Development Needs ...................................................................................

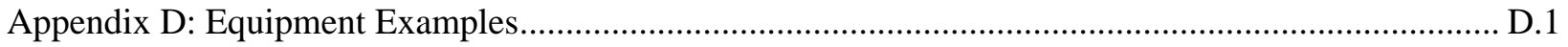

\section{Figures}

2.1. Commercial Size Electrochemical Module …............................................................................. 2.3

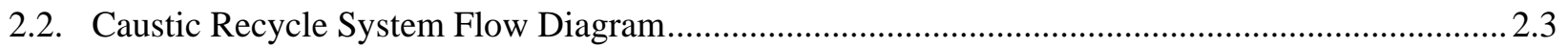

4.1. Flow Diagram for Na Recycle Connections to WTP................................................................... 4.1

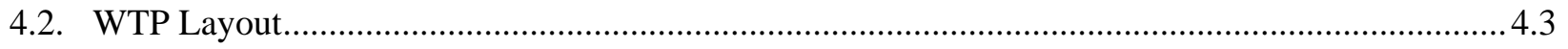

4.3. Laboratory and Pilot Scale Electrochemical Reactor Modules ................................................... 4.5

\section{Tables}

1.1. Mass Balance Summary per Process Train for Na Recycle........................................................ 1.2

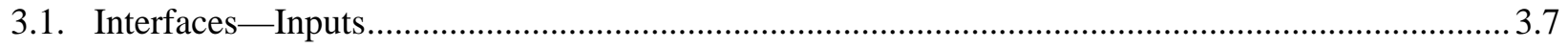




\subsection{Introduction}

Sodium is one of the most common components of the Hanford tank wastes and is a major contributor to the waste-oxide loading in the low-activity waste (LAW) glass. In addition to the large amounts of sodium already in the wastes, the current waste-treatment approach calls for adding additional sodium (primarily as $\mathrm{NaOH}$ ) during the pretreatment of the tank wastes and for corrosion control in the tank farms, potentially increasing the volume of LAW glass. Since the tank wastes already contain significant amounts of sodium, there is a potential benefit for a caustic recycle process that would separate sodium hydroxide for recycle at the Hanford site. This would reduce the volume of LAW glass and minimize the need to purchase new $\mathrm{NaOH}$.

The current pretreatment flowsheet indicates that approximately $6500 \mathrm{MT}$ of Na will be added to the tank waste, primarily to remove $\mathrm{Al}$ from the high-level waste (HLW) sludge (Kirkbride et al. 2007). Future estimates on sodium requirements for caustic leaching are expected to significantly increase the current value to dissolve sufficient $\mathrm{Al}$ from the tank waste sludge material to minimize the number of HLW canisters produced.

Electrochemical salt-splitting technologies for caustic recycle were investigated in the 1990s for application to the treatment of tank wastes at the Hanford, Savannah River, and Idaho National Engineering Laboratory (INEL) sites. These investigations, which were primarily funded by the EM-50 Efficient Separations and Processing Program, included testing of commercially available organic-based ion exchange membranes (i.e., Nafion) and ceramic-based sodium selective membranes (NaSICON) developed by Ceramatec Inc. Both membrane types were tested with simulants at the pilot scale and with actual radioactive waste samples at the bench scale. The Nafion membranes were found to have a lower current efficiency than the ceramic membranes and transported radioactive cesium at a higher rate than the sodium, resulting in a contaminated caustic product.

The likely increase in the caustic requirement for pretreatment of the tank wastes has resulted in renewed interest in caustic-recycle methods for sludge washing and Leaching. Ceramatec Inc. has continued to develop the NaSICON membranes for caustic recycle. As part of this development effort, Ceramatec has engaged staff at Pacific Northwest National Laboratory (PNNL) to assist with applying this technology for caustic recycling at Hanford. This report addresses the preconceptual design in the deployment of such a facility at Hanford. The facility would be located near the Waste Treatment Plant (WTP) Pretreatment Facility.

A flowsheet was developed to determine the number of electrochemical modules and flow rates for the process. The flowsheet information was used as the basis for a preliminary layout and design of a processing facility and to prepare some design requirements. The primary design requirement is for the facility to recycle 23,000 MT of Sodium over a 20 year period. The flowsheet is shown in Figure B.1 in Appendix B, and a summary of the flowrates and mass-balance calculations are provided in Table 1.1. The information was also used to support a cost evaluation (Poloski et al. 2007). 
Table 1.1. Mass Balance Summary per Process Train for Na Recycle

\begin{tabular}{|c|c|c|c|c|c|c|c|c|c|}
\hline Description & Units & $\begin{array}{c}\text { HLW } \\
\text { Tank } \\
\text { Waste } \\
\text { Feed } \\
\end{array}$ & $\begin{array}{c}\text { HLW } \\
\text { Tanks } \\
\text { Exit }\end{array}$ & $\begin{array}{c}\text { Anolyte } \\
\text { Return } \\
\text { per loop }\end{array}$ & $\begin{array}{c}\text { Anolyte } \\
\text { Feed per } \\
\text { loop }\end{array}$ & $\begin{array}{c}\text { Catholyte } \\
\text { Return } \\
\text { per loop }\end{array}$ & $\begin{array}{c}\text { Catholyte } \\
\text { Feed per } \\
\text { loop }\end{array}$ & $\begin{array}{c}\text { Caustic } \\
\text { Tank } \\
\text { Makeup } \\
\end{array}$ & $\begin{array}{c}\text { Caustic } \\
\text { Tank } \\
\text { Exit } \\
\end{array}$ \\
\hline Temperature & ${ }^{\circ} \mathrm{C}$ & 25 & 45 & 45 & 45 & 45 & 45 & 25 & 25 \\
\hline Flow rate & $\mathrm{L} / \mathrm{min}$ & 48 & 48 & 2809 & 2811 & 2812 & 2811 & 3.0 & 4.0 \\
\hline Density & $\mathrm{kg} / \mathrm{L}$ & 1.2 & 1.2 & 1.2 & 1.2 & 1.5 & 1.5 & 1.0 & 1.5 \\
\hline Mass flow & $\mathrm{kg} / \mathrm{min}$ & 57 & 55 & 3371 & 3373 & 4268 & 4266 & 3 & 6 \\
\hline Concentration $\mathrm{OH}$ & $\mathrm{M}$ & 2.4 & 0.9 & 0.8 & 0.9 & 19 & 19 & 0 & 19 \\
\hline Concentration $\mathrm{Na}$ & $\mathrm{M}$ & 4.7 & 3.2 & 3.2 & 3.2 & 19 & 19 & 0 & 19 \\
\hline Concentration Al & M dissolved & 0.18 & 0.18 & 0.18 & 0.18 & 0.00 & 0.00 & 0.00 & 0.00 \\
\hline
\end{tabular}




\subsection{System Identification}

The Caustic Recycle System (CRS) is part of a supplemental facility proposed to reduce the cost and waste generation for the Hanford WTP operations. The process would include all necessary equipment for receiving LAW waste from the WTP pretreatment facility, returning a LAW stream with a lower Na content, and providing a stream of concentrated $\mathrm{NaOH}$ to be used in the WTP sludge-leaching system. The facility will have its own the process vessel ventilation system, cooling water, power distribution, and miscellaneous utilities. The system is based on NaSICON ceramic membrane technology. An earlier report on the preconceptual design of the electrochemical cell was reported in 1997 by Kurath et al. (1997a).

\subsection{Limitations of this System Design}

This system design description includes information for the process equipment to support a request for proposal for a conceptual design and bottoms-up cost estimate for the entire facility. The cost estimate in this description is based on scaling to the WTP Vitrification Facility size and Monte Carlo analyses of other costs and benefits. The details of the cost analysis are provided in a separate report by Poloski. The design description is limited to current information, and the further details will be developed during the conceptual-design process when additional information is available and additional process requirements are be imposed.

\subsection{Ownership of this System Design}

This system description is controlled by Ceramatec and PNNL. 


\subsection{General Overview}

This section describes the primary functions of the CRS, its classification, and its basic operations.

\subsection{System Functions}

The primary functions of the CRS are to remove Na from the pretreated (caustic leach, filtration, and Cs ion exchange) LAW stream received from WTP, return the LAW stream to WTP for vitrification, and return the $\mathrm{Na}$ as $\mathrm{NaOH}$ for caustic leaching. The removed Na would be used to produce a concentrated $\mathrm{NaOH}$ ( 19 M) stream to be delivered to WTP for dissolving aluminum from the WTP gibbsite-, boehmite-, and chromium-laden sludge feed streams. The technology for the Na removal system is an electrochemical cell using a ceramic membrane. The ceramic membrane was selected as a technology that could produce concentrated $\mathrm{NaOH}$ without transporting significant radionuclides to the $\mathrm{NaOH}$ product.

The receipt and return of the WTP LAW would be accomplished through spare nozzles in the WTP north pipe trench. The receipt of the LAW would be from the cesium ion exchange (CXP) outlet stream that is collected in the CXP tanks. The liquid stream would be transferred after it is analyzed to verify Cs removal, thus making sure that dose rates are acceptable for the contact-maintained CRS facility. The return of the electrochemical-treated LAW would be through the pipe trench and possibly to the LAW Submerged Bed Scrubber (SBS) recycle tank (TLP-09). The CRS receipt storage tank will be of sufficient size to allow for 12 hours of operation without WTP feed or could be sized to match the Pretreatment Facility CXP tank batch-transfer size. The feed would be processed to remove Na and produce concentrated $\mathrm{NaOH}$ with a recirculation loop between feed tanks in this facility and the electrochemical cells operated at temperatures between 40 and $60^{\circ} \mathrm{C}$. The LAW would recirculate through the anode side of an electrochemical reactor with a Ceramatec ${ }^{\circledR}$ membrane barrier separating the cathode side. The Na would be collected and concentrated in another recirculation loop through the cathode side of the electrochemical cell. The collected $\mathrm{NaOH}$ would be transferred to a product tank and analyzed before transferring back to WTP. The product would be recycled back to the receipt tank in case of catastrophic membrane failure.

\subsection{System Classification}

The facility would have a preliminary classification as Hazard Category $3^{(a)}$ based on the quantity of radionuclides in the system. This classification is based on risk to the workers and the public based on uptake of radionuclides during and after an accident that disperse material in the facility. Some ventilation equipment is preliminarily classified as Safety Significant because of the hydrogen generated in the electrochemical cells and the large flow rate of radioactive materials around the cells.

(a) DOE-STD-1027-92, 1992 DOE Standard Hazard Categorization and Accident Analysis Techniques for Compliance With DOE Order 5480.23, Nuclear Safety Analysis Reports, U.S. Department of Energy Washington, D.C. 20585 


\subsection{Basic Operational Overview}

The Na recycle system consists of six primary sub-systems.

Process System

Electrochemical Receipt Tank (ERT)

Electrochemical Feed Tank (EFT)

Electrochemical Return Buffer Tank (ERBT)

Electrochemical Reactor (ECR)

Electrochemical Caustic Tank (ECT)

$\mathrm{NaOH}$ Product Tank (NPT)

The process system is supported by the Caustic Recycle Building and a number of support systems. These systems consist of the following:

Cooling Water System
Electrical Supply System
Process Ventilation System
Building Safety and Structural Systems
Building Heating and Ventilation
Water and Miscellaneous Utilities
Process Control System

Some requirements for the support systems are described in this document to provide a preliminary idea of the space needed for the electrochemical process and a layout of a building.

\subsubsection{Process System}

\subsubsection{Overall Description}

The overall system provides for recirculation loops of LAW and $\mathrm{NaOH}$ that pass through multiple electrochemical modules in parallel. One module is shown in Figure 2.1 and contains many membranes and cells. The flow loops are supported by buffer tanks to receive and transfer material to the WTP pretreatment facility as shown in Figure 2.2. The fluid flow to the modules is in parallel to allow for gas separation in the outlet pipes without requiring special gas separation devices between modules. Gas buildup in the modules prevents efficient operation. The modules are also located at the same level to minimize total pressure against the membranes and for ease of maintenance. The system would reside in a contact-maintainable facility, although most module maintenance would be performed in a separate area for ALARA reasons and to maximize operating efficiency. Replacement electrochemical modules would be available for rapid change-out, while the module requiring maintenance would be moved with a crane to a separate area. All the tanks and piping would be fabricated with stainless steel to reduce fire loading while significant parts of the cells and pumping systems may be polyethylene. Preliminary evaluation indicates that the process system would be housed in a Category 2 radiological facility because of the inventory in the large storage tanks. The facility will contain process and building ventilation systems to mitigate environmental releases and for worker protection. The power supplies for the modules are large and would be placed in a room alongside the main processing room as seen in the layout in Figure B.2 in Appendix B. The overall electrical needs and some typical equipment are shown in Tables B1 and B2. 
Some shielding is required around the storage tanks and large pipelines to allow for contact maintenance. The LAW vitrification facility has similar radionuclide content although the dose rate estimates take credit for 1 inch thick steel shell and refractory lining on the melter to provide the required shielding for contact maintenance.

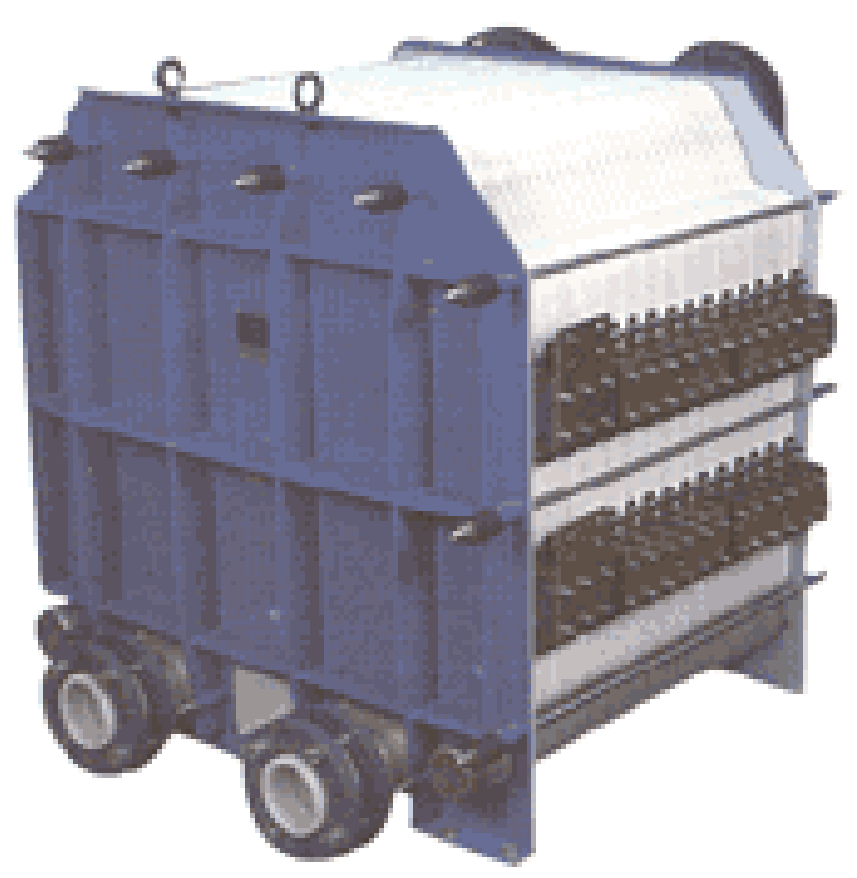

Figure 2.1. Commercial Size Electrochemical Module

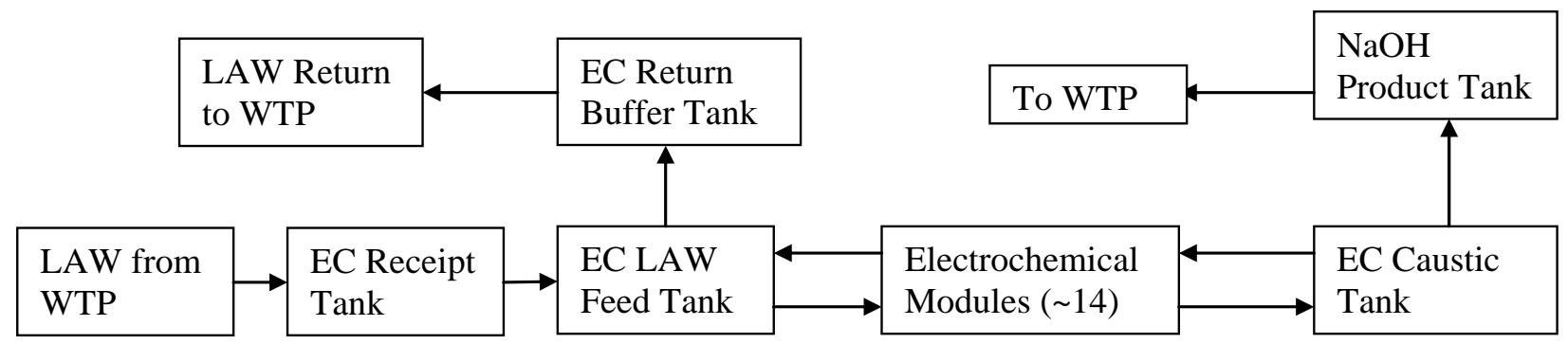

Figure 2.2. Caustic Recycle System Flow Diagram

The building would be a canyon-type facility with an overhead crane. The central canyon would be enclosed by a concrete wall with electrical cabinets, controls, and cooling-water services supplying the electrochemical (EC) system from rooms on the other side of the canyon walls. The canyon area would be a Zone 2 ventilation system with induced draft fans and high-efficiency particulate air (HEPA) filtration before sending the exhaust to the environment. The process system would have a separate vessel ventilation system that exhausts into the main building ventilation ducts. 


\subsection{Requirements and Bases}

This section describes primary system functional requirements and WTP assumptions as well as the requirements of the subsystem and major components (including process equipment, monitoring instruments, essential features, radiological requirements, system upsets, maintenance, environment, and ventilation). It also describes boundaries and interfaces.

\subsection{System Functional Requirements and WTP Assumptions}

The primary system functional requirements are:

- Process System shall be able to produce 1600 metric tons (MT)/year of $\mathrm{NaOH}$ from Hanford LAW waste with a $60 \%$ operating efficiency.

- Electrochemical cells shall transfer 23,000 MT of sodium from the waste over 25 years.

- The Hanford LAW waste has been aluminum leached and ion-exchanged.

- Facility design life shall be for 25 years.

- Process system shall be capable of operating for 12 hours without transfers to or from WTP.

- System shall produce $50 \mathrm{wt} \% \mathrm{NaOH}$ solution at a rate of 8.0 liters/min.

- System shall be able to receive 60,000 liters of feed that results in a dose rate less than $5 \mathrm{mrem} / \mathrm{hr}$, which is $30 \mathrm{~cm}$ from the receipt tank in a normally maintained area.

- System shall be designed for remote operation but contact maintenance.

- System components shall be designed to allow for remote replacement or removal (crane and impact wrench) for all equipment with life $<1$ year and contact maintained for other equipment.

- Contamination from the process shall be confined and controlled within the processing area.

The primary WTP assumptions (or Bases) are:

- 23,000 MT of Na are available for recycle.

- The process connection to WTP can be made in the North Pipe Trench.

- The NaOH product can be sent directly to the WTP pretreatment chemical make-up tanks as there is a pipe stub for contaminated $\mathrm{NaOH}$ from the Fast Flux Test Facility (FFTF).

- Transfers to and from WTP can be made in less than 12-hour intervals. 


\subsection{Subsystem and Major Components Requirements}

\subsubsection{Process Equipment Requirements}

\subsubsection{Electrochemical Modules}

R3.1. Maximum weight for electrochemical modules shall be less than capacity of the bridge crane (estimated capacity: 10 tons).

Basis: Modules shall not exceed the capacity of the bridge crane for the facility to allow easy replacement.

R3.2. The pressure differential across the membranes shall be controlled to be less than 2 psig at all times.

Basis: Membrane specifications.

R3.3. The NaSICON Membrane System shall be capable of producing $19 \mathrm{M} \mathrm{NaOH}$ with impurities such that the dose rate is less than $0.2 \mathrm{mrem} / \mathrm{hr}$.

Basis: $\mathrm{NaOH}$ produced has to be acceptable for the WTP plant chemical make-up room.

R3.4. Shielded radiation detectors shall be installed on the catholyte outlet of each module to detect membrane failure.

Basis: Prevent contamination of $\mathrm{NaOH}$ product and identity modules requiring service.

R3.5. Modules and recirculation piping require the ability to be flushed for maintenance. Flush solution may be returned to feed tank and be treated after maintenance completed.

Basis: Minimize contamination of $\mathrm{NaOH}$ product.

R3.6. ECR module process and electrical connections will be accessible for installation using a crane and impact wrench or easy no-drip connections.

Basis: Minimize dose to the workers when modules need to be changed.

R3.7. Module shall have secondary containment for liquids (drip pans).

Basis: Minimize the spread of contamination in case of leaks and for clean-up efficiency.

R3.8. Module shall operate at a nominal capacity of $100 \mathrm{~mA} / \mathrm{cm}^{2}$ of membrane area.

Basis: Design Specification

\subsubsection{Process Tanks}

R3.9. The tanks shall be designed with inlet and outlet connections near the top of the tank.

Basis: Bottom outlets or connections have greater tendency for leaking and draining the tank.

R3.10. EC Receipt Tank shall be large enough to supply the EC Feed Tank for 12 hours.

Basis: Provide buffer storage to prevent interruptions during processing caused by feed delivery from WTP. 
R3.11. The EC caustic tank feed pump and EC LAW feed pump shall be capable of producing variable flow over the range that supports turbulent flow in the EC cells. The flow rate is estimated to be 200 to $300 \mathrm{~L} / \mathrm{min}$ per module or $3500 \mathrm{~L} / \mathrm{min}$ per line with differential pressures across the modules less than 1 psig.

Basis: Turbulent flow is required for efficient operation of the EC cells, and low pressures are required to prevent membrane failures.

R3.12. The feed tank shall be equipped with a means of measuring volume to an accuracy greater than \pm 20 liters.

Basis: Control operations and verify solution quantity.

R3.13. The feed tank shall be equipped with a level monitors and alarms.

Basis: Prevent overfilling tank.

R3.14. The EC feed tank and return tanks shall have mechanical agitators to suspend precipitated solids that may form during processing.

Basis: Agitators are required so solids can be removed from the process system

\subsubsection{Transfer Pumps}

R3.15. The LAW feed-transfer pump shall be capable of pumping at a nominal rate of $1000 \mathrm{~L} / \mathrm{min}$ at a pressure $\leq 60$ psig.

Basis: The transfer pump will be required to transfer slurry at rates that support the processing-rate range of the electrical chemical modules.

R3.16. The $\mathrm{NaOH}$ feed-transfer pump shall be capable of pumping solutions with a specific gravity from 1 to 1.6 and a viscosity of $50 \mathrm{wt} \% \mathrm{NaOH}$.

Basis: There is an operational need for feed and product solutions.

R3.17. The feed delivery system to the EC feed tank (P1) shall be capable of delivering variable feed flow from 50 to $200 \mathrm{~L} / \mathrm{min}$.

Basis: The level in the EC Feed Tank shall be controlled for operating at variable flows through the electrochemical cells.

R3.18. The EC caustic tank feed pump and EC LAW feed pump shall be capable of producing variable flow over the range that supports turbulent flow in the EC cells. The flow rate is estimated to be 3000 to $5000 \mathrm{~L} / \mathrm{min}$ in the recirculation loop at pressures less than 5 psig.

Basis: Turbulent flow is required for efficient operation of the EC cells, and low differential pressures are required to prevent membrane failures.

R3.19. Jet Pumps used for draining the tanks completely shall have suction at the low point of the tanks and have an outlet pressure $>10$ psig. Flow rates shall be permit the pumps to empty a full tank in less than four hours.

\subsubsection{Process Piping}

R3.20. The piping shall be routed to prevent dead-legs, liquid hold-up, back-flow, and siphoning outside of designated contamination areas. 


\section{Basis: Contamination prevention and plugging.}

R3.21. Inlet piping to the EC cells shall be designed to drain back to the recirculation tank.

Basis: Allow for efficient flushing and minimize inventory during replacement

R3.22. Outlet piping from EC cells shall be designed to drain back to the EC cells and sloped up to the recirculation tanks to avoid gas accumulation in the pipelines.

Basis: Allow for efficient flushing and minimize inventory during replacement and prevent gas bubbles in pipeline restricting liquid flow. Gas generated from the ECR will be vented to the ventilation system where the return enters the downcomer line to the tank.

R3.23. Pressure drop in recirculation piping shall be less than 2 psig. Differential pressure shall be alarmed.

Basis: Prevent accidental over-pressurization of EC cells.

R3.24. Piping connections shall be designed to be disconnected with a crane if component life is less than 1 year.

Basis: Minimize worker dose and time in highly contaminated area.

R3.25. The transfer pipe and annulus to and from the Pretreatment Facility shall be sloped towards the Pretreatment Facility.

Basis: Prevent hold-up in the piping system and match transfer slopes to other WTP facilities from the pretreatment facility.

\subsubsection{Process Monitor Instrumentation}

R3.26. An in-line mass-flowmeter probe, a Raman spectrometer (Bryan et al. 2008) and specific gravity monitors shall be incorporated in the recirculation loops for each ECR system to provide for characterization of the feed and ECR outlet streams. The mass-flowmeter probe shall cover a specific-gravity range of 1 to 1.6 with an repeatability of $\pm 5 \%$.

Basis: The in-line Raman spectrometer-based monitoring system will be capable of estimating dissolved aluminate and hydroxide ion concentrations in the LAW to control the precipitation of aluminum compounds (i.e., Gibbsite).

\subsubsection{Essential Feature Requirements}

R3.27. High $\mathrm{NaOH}$ concentrations may cause erosion of pipes, valves, and other components. All equipment handling solutions shall be capable of performing their function for 30 years or be readily replaceable.

Basis: Prevent excessive downtime of processing equipment and radioactive waste generation in the event of equipment failure.

R3.28. All pumps, valves, mixers, and actuators shall be designed for remote operation and contact maintenance.

Basis: Allow remote operation of the equipment for ALARA concerns. 
R3.29. A cooling system shall be capable of removing heat equal to 1.5 times the excess power used to operate cells and maintain the system at less than $40^{\circ} \mathrm{C}$. This design requirement is estimated at $500 \mathrm{~kW}$.

Basis: A temperature limit may be required to make sure that the membrane will have a long operating life, and the reactor inefficiencies may generate enough heat to exceed equipment operating limits.

\subsubsection{Radiological Requirements}

\subsubsection{ALARA Requirements}

R3.30. The design of the NaSICON Membrane System shall meet the requirements of 10 CFR 835, Occupational Radiation Protection, Subpart K, Design and Control.

\section{Basis: ALARA}

R3.31. Engineered controls (i.e., shielding, automation, and remote handling) shall be used throughout the process (including maintenance of processing equipment) to maintain personnel radiation exposure below an average of $0.5 \mathrm{mrem} / \mathrm{h}$ for continuous occupancy (2000 hours) and ALARA. For non-continuous occupancy, the whole body-design dose objective is to maintain doses ALARA and less than 1 rem per year. The extremity design dose objective is to maintain doses ALARA and less than 10 rem per year.

\section{Basis: ALARA}

\subsubsection{Contamination Requirements}

R3.32. Confinement and ventilation will be used in the process to avoid hazardous, explosive, or radioactive releases to the workplace or environment.

Basis: ALARA to control the inhalation of such material by workers or the public and to avoid explosive gas concentrations.

\subsubsection{System Upset Requirements}

R3.33. The $\mathrm{NaOH}$ tank must have temperature control from 20 to $80^{\circ} \mathrm{C}$ so the viscosity of high concentration of $\mathrm{NaOH}$ solutions can be reduced and pumped effectively.

Basis: The process must be capable of recovery from out-of-specification $\mathrm{NaOH}$.

R3.34. The system shall be designed such that recovery from a power failure is possible at any stage of the process with a minimum of manual intervention.

Basis: Prevent possible accident or increased dose upon restart.

R3.35. Secondary system is required for emptying the LAW and caustic-recycle feed tanks.

Basis: Minimize dose rates for maintenance on tanks and electrochemical reactors.

\subsubsection{Maintenance Requirements}

R3.36. The system shall be designed for crane access to major equipment parts.

Basis: Masked entrance for maintenance should only be performed for components with a meantime between failures that is longer than 1 year. 
R3.37. The LAW Receipt tank shall be designed for crane access through cover blocks.

Basis: ALARA; remote maintenance required on large equipment with a significant inventory of waste material.

R3.38. The contact-maintained equipment should be designed for a life of greater than 1 year.

Basis: ALARA; masked entrance for maintenance should only be performed for components that can be flushed and have a mean-time between failures $<1 \mathrm{yr}$.

\subsubsection{Environmental Requirements}

R3.39. Secondary containment is required for all process containers, piping, and equipment that contain LAW solutions.

Basis: The feed material is designated as Washington State listed waste that requires secondary containment to comply with the Washington Administrative Code (WAC).

\subsubsection{Process Ventilation Requirements}

R3.40. Condensers, demisters, and HEPA filters are required on the final tank exhaust. Other gases exceeding environmental limits may also require destruction or clean-up.

Basis: Minimize loss of condensate from the tanks and prevent toxic particulate and releases of gases to the environment.

\subsection{Boundaries and Interfaces}

This process system includes the tanks, pumps, piping, ECR modules, and process instrumentation within the building. The boundaries for the piping are the pipe-trench connection points and the main power distribution panel within the building. The process system has a boundary with the electrical system at the termination panels on the ECR modules, pumps, and process instrumentation. The chilled water boundaries are at the connection point to the ECR modules and tanks. Table 3.1 describes the interfaces and lists the sources. 
Table 3.1. Interfaces-Inputs

\begin{tabular}{|c|c|c|}
\hline Source & Description & $\begin{array}{c}\text { Interface } \\
\text { Type } \\
\text { P-Physical } \\
\text { F-Functional }\end{array}$ \\
\hline Feed Transfer To/from WTP & $\begin{array}{l}\text { Provides the control of transfers between WTP and the Sodium } \\
\text { Recycle Facility and the connection points. }\end{array}$ & $\mathrm{P}$ and $\mathrm{F}$ \\
\hline Process Chilled Water System & $\begin{array}{l}\text { Supply process cooling water to cool EC Modules, LAW Feed } \\
\text { Tank, and EC caustic Tank. Process needs a supply of } 35^{\circ} \mathrm{C} \\
\text { cooling water to remove } 300 \mathrm{~kW} \text {. }\end{array}$ & $\mathrm{P}$ and $\mathrm{F}$ \\
\hline Remote Handling System & Provides cranes to support the processing system maintenance. & $\mathrm{P}$ and $\mathrm{F}$ \\
\hline Process Control System & $\begin{array}{l}\text { Sends/receives instrument signals and/or serial data from process } \\
\text { instrumentation to measure flowrates, temperature, density, and } \mathrm{Na} \text {, } \\
\text { Aluminate and hydroxide concentrations. }\end{array}$ & $\mathrm{P}$ and $\mathrm{F}$ \\
\hline Ventilation System & $\begin{array}{l}\text { Provides ventilation and radionuclide control for the EC system, } \\
\text { including the tanks. Also provides building ventilation. ECR } \\
\text { process will produce hydrogen at a rate that requires dilution. }\end{array}$ & $\mathrm{F}$ \\
\hline $\begin{array}{l}\text { Electrical Power Distribution } \\
\text { System }\end{array}$ & $\begin{array}{l}\text { Interface between power supplies for process power system and } \\
\text { building electrical needs. Process will provide electrical needs. } \\
\text { WTP substation for power source. }\end{array}$ & $\mathrm{F}$ \\
\hline $\begin{array}{l}\text { Instrument and Compressed Air } \\
\text { System }\end{array}$ & $\begin{array}{l}\text { Interface between instrument and compressed air system at } \\
\text { equipment connection points. Process systems will provide needs. }\end{array}$ & $\mathrm{P}$ and $\mathrm{F}$ \\
\hline Building Structures and Systems & $\begin{array}{l}\text { Process will supply equipment sizes and weight for building } \\
\text { structures. Building structures will supply seismic criteria. }\end{array}$ & $\mathrm{P}$ \\
\hline Storage of supplies & $\begin{array}{l}\text { Process interface includes identification of supplies and inventory } \\
\text { requirements. }\end{array}$ & $\mathrm{F}$ \\
\hline
\end{tabular}




\subsection{System Description}

This section describes the configuration of the building, the system, the subsystems, and the major components. A flow diagram showing the connections to WTP is shown in Figure 4.1. This section also describes operations in the facility, including the initial configuration, system startup, normal operations, off-normal operations, and system shutdown.

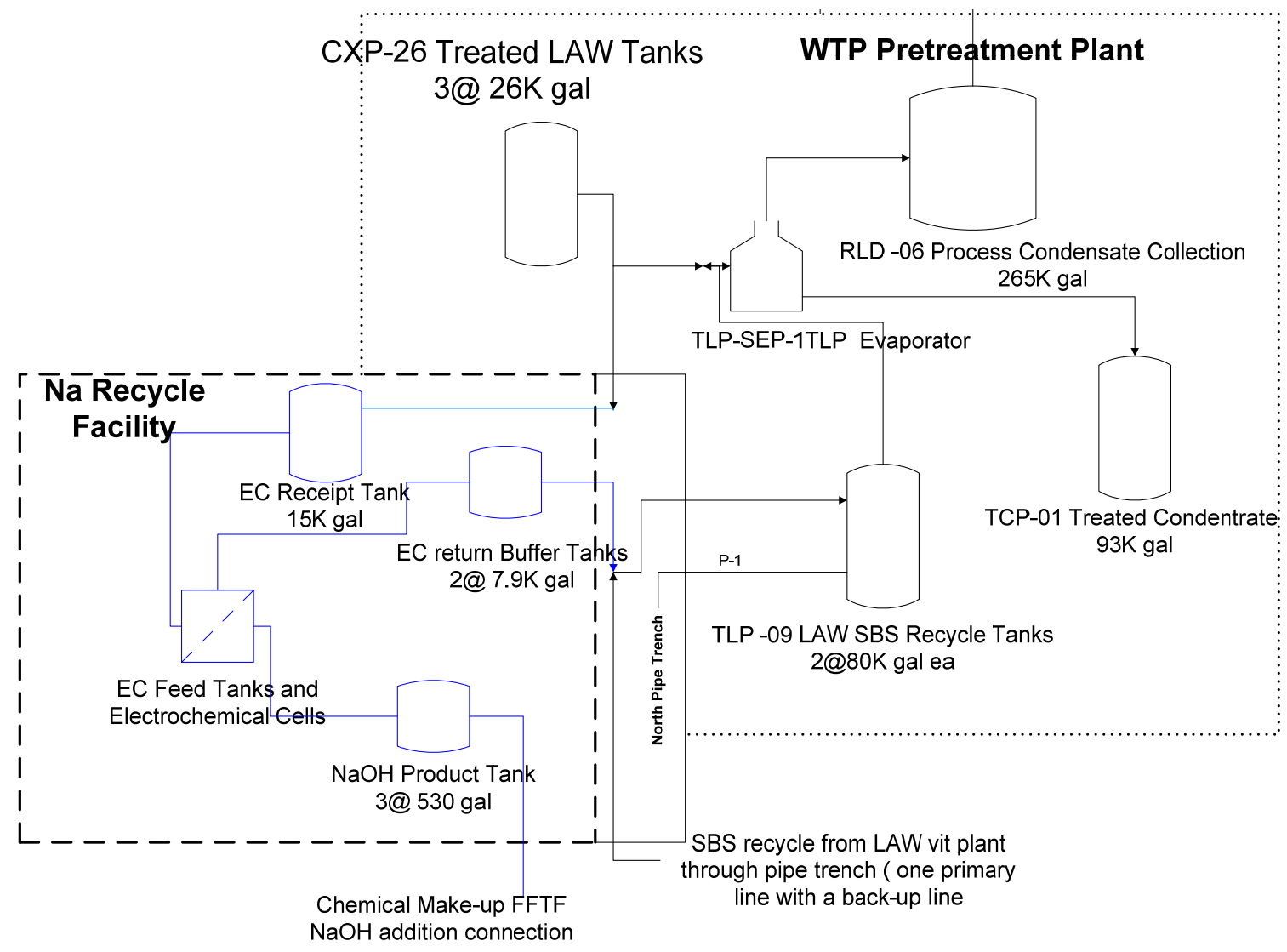

Figure 4.1. Flow Diagram for Na Recycle Connections to WTP

\subsection{Configuration Information}

\subsubsection{Building}

The building will be a rectangular concrete structure with a small number of offices. A rectangular center section that is approximately $80 \mathrm{ft}$ long and $35 \mathrm{ft}$ wide will house the process equipment handling the LAW and will be supported with an overhead bridge crane and/or manipulator. The area will be considered a contamination area and a radiation area. The electrical power, cooling water, and other service will be maintained outside the contamination area with piping and bus bars passing through the wall or the floor. Ventilation for the center contamination area will be directed to ventilation tunnels underneath the operating rooms surrounding the contamination areas. Ventilation will cascade from the clean areas to the contaminated areas and then the air flow will be filtered and sent out the stack. The area along the side of the process room will contain a large number of DC electrical power systems and 
the control system for the process. The corridor on the side of the processing area opposite the control room will also house the $\mathrm{NaOH}$ product tanks.

One end of the processing area will be used for an airlock that will allow module change-out and maintenance. The airlock will contain a containment area to service the ECR modules and will have a connection to the Feed Receipt Tank for flushing the modules. The airlock will also serve as a service area for the EC receipt tank. Next to the airlock will be a truck bay for bringing in equipment and eventually loading out waste from failed process equipment. The truck bay will also be serviced with an overhead crane with a 20-ton capacity. The other end of the building outside the process area contains cooling-water heat exchangers, cooling-water pumps, process-ventilation filters, ventilation blowers, and other miscellaneous building services. The building layout and elevation sketches are shown in Figures B.2 and B.3 in Appendix B. The overall dimensions of the building are $120 \mathrm{ft}$ long, $70 \mathrm{ft}$ wide, and $25 \mathrm{ft}$ from the main floor to the bridge crane.

The building could use power brought in from the WTP substation unless another LAW Vitrification Melter is needed. If sufficient power is not available, a review of power supplies is needed. A layout of the WTP site is shown in Figure 4.2.

\subsection{Description of System, Subsystems, and Major Components}

\subsubsection{Process System}

\subsubsection{Electrochemical Receipt Tank}

The receipt tank is used to provide lag time between deliveries of feed from the WTP pretreatment system. The feed would be supplied from the treated LLW $26 \mathrm{~K}$ gal (98 K liter) CXP tanks through a spare nozzle in the north pipe trench. The ECR Tank is 60,000 liters and will support Na recycle operations for $>12$ hours before another transfer is needed. This is a large tank that would be placed below grade with limited cover block access for servicing transfer pumps and instrumentation. The tank is not provided with agitation as solids are not expected from the CXP tanks in the WTP pretreatment facility.

An alternative to the ECR Receipt Tank is to use the pretreatment CXP tanks directly to supply the ECR feed tanks on a continuous basis, eliminating the need for the ECR receipt tank. Operating system integration and controls between buildings would cause some difficulties, and this is not part of this design description. Different sizes for the receipt tank could also be considered to accommodate various batch sizes from the pretreatment facility or to match planned batch-transfer sizes from the pretreatment facility.

The tank fabrication will be made with heavy wall stainless steel to reduce the dose rate at the top of the vessel. Additional shielding between the vessel and the airlock other than a typical airlock door is not expected to be required. 


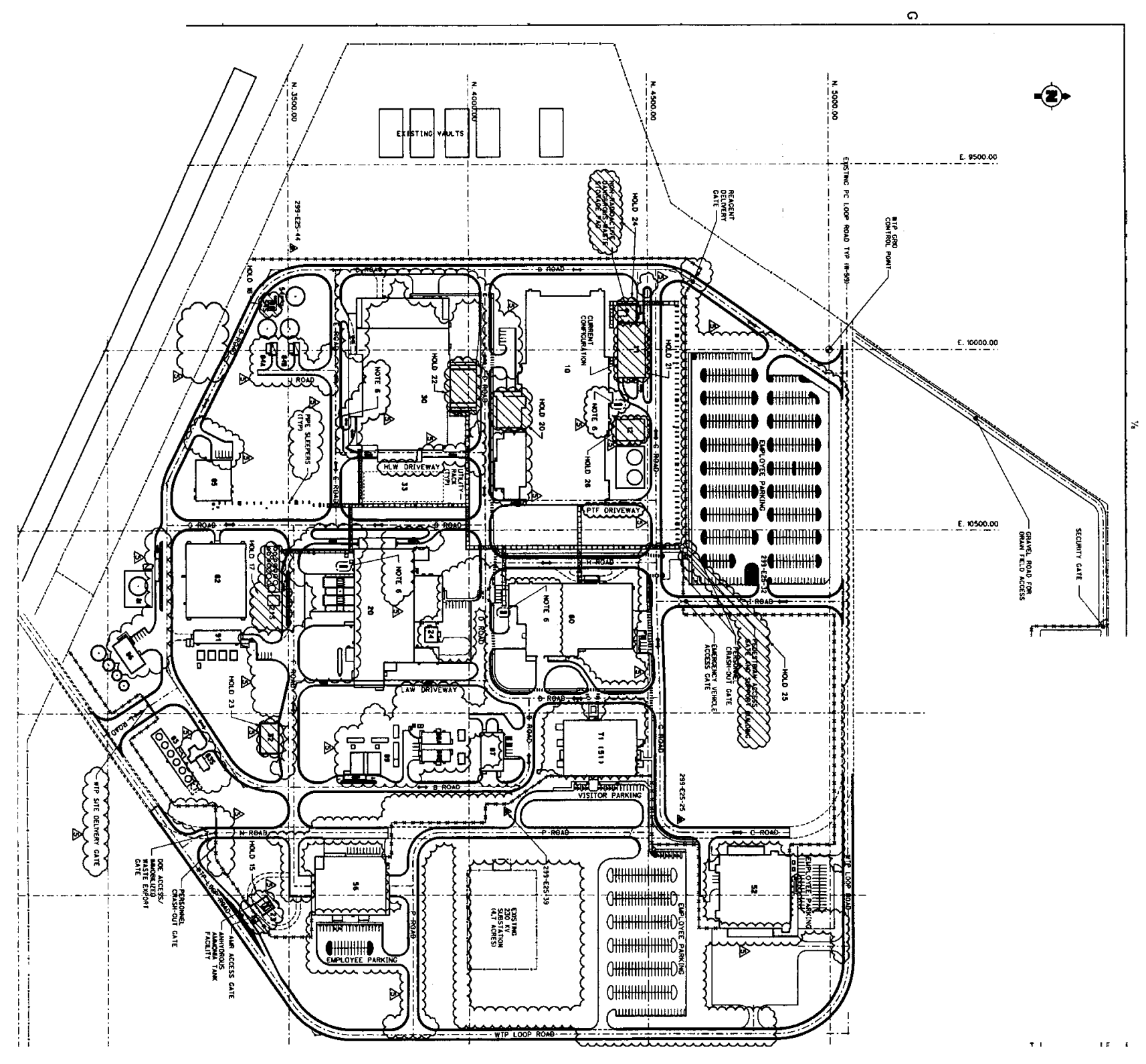

Figure 4.2. WTP Layout 


\subsubsection{Electrochemical Return Buffer Tanks}

The ERTs consist of two tanks with a total of 12 hours of operating capacity before transfers are required to WTP. The two-tank system allows for sampling or analytical information to be made before transfer to WTP. The system includes two 30K liter tanks with separate transfer pumps that feed a single transfer line to a tank that feeds the TLP evaporator. The returned material could also be used to increase the $\mathrm{pH}$ of the LAW SBS recycle stream. If feed to the evaporator was interrupted from the ERT or the waste did not require processing because of low excess Na concentrations, then WTP could still feed the evaporators directly from the CXP tanks, and only the Na removal from the waste would be lost.

The tank fabrication will be made with heavy wall stainless steel to reduce the dose rate around the vessel. The vessel will be located below the level of the ECR in a steel-lined concrete sump area. The position will provide radiation shielding between the vessel and the operating area as well as secondary containment for leaks, including flushing the floor area used by the ECRs.

\subsubsection{Transfer Pumps}

The pumps used to deliver the LAW to the receipt tanks will be centrifugal pumps capable of 500 to $1000 \mathrm{~L} / \mathrm{min}$. The LAW feed back to the WTP facility will likely contain solids, and the pump will be required to handle dilute slurries. The caustic feed will be pumped at approximately 25 to $30^{\circ} \mathrm{C}$ at a concentration up to $19 \mathrm{M} \mathrm{NaOH}$. The flow rate for the caustic feed pump is 50 to $100 \mathrm{~L} / \mathrm{min}$.

\subsubsection{Recirculation Pumps and Piping}

The pumps used to recirculate the LAW and the $\mathrm{NaOH}$ through the ECR modules will be low-head centrifugal pumps capable of 3000 to $5000 \mathrm{~L} / \mathrm{min}$. The pumps could be vertical cantilevered pumps to avoid connection at the bottom the tank and to allow for draining the feed loops back to the tanks. The LAW feed and caustic feed will be pumped at approximately $40^{\circ} \mathrm{C}$ at a concentration up to $19 \mathrm{M} \mathrm{NaOH}$. An example of such a pump is an $8 \times 6 \times 10$ model operated at $835 \mathrm{rpm}$ as shown in Appendix D. Additional steam jet-transfer pumps should be added as back-up and for completely emptying the tanks inside the Electrochemical Processing Facility.

The piping in the recirculation loops shall be designed to drain back to the feed tanks through the ECR to aid maintenance and to allow the outlet lines of the ECR to be sloped slightly upwards to prevent gas pockets from the gas generated in the ECR. The pipes should be of sufficient size to accommodate the liquid flow rate and the gas generation rate from the cells with a minimal pressure drop. The ceramic membranes cannot withstand large differential pressure, and the pressure in the recirculation loop must be controlled.

\subsubsection{Electrochemical Reactor Modules}

The electrochemical reactor (ECR), which is a two compartment ElectroProd ${ }^{\mathrm{TM}}$ cell with a Ceramatec ${ }^{\mathrm{TM}}$ membrane to separate the anolyte and the catholyte, is shown in Figure 4.3. Each module will have a set of 40 parallel cells with a $\mathrm{NaOH}$ production capacity of $0.34 \mathrm{~L} / \mathrm{min}$ of $19 \mathrm{M}$ solution based on current density of $100 \mathrm{~mA} / \mathrm{cm}^{2}$. The facility may contain a total of 28 modules in a parallel configurations to minimize cost and allow independent operation if one module or system should have operating difficulties. The flow rate through each module is $\sim 200 \mathrm{~L} / \mathrm{min}$, and the pressure drop is less than 0.1 psig. Dry disconnects should be used, and estimates of dose rates to workers from maintaining the ECR 
modules should be determined. If dose rates are high, the connection to the module will be 2- to 3-inch plutonium-uranium extraction (PUREX) connectors, or additional localized shielding would be required.
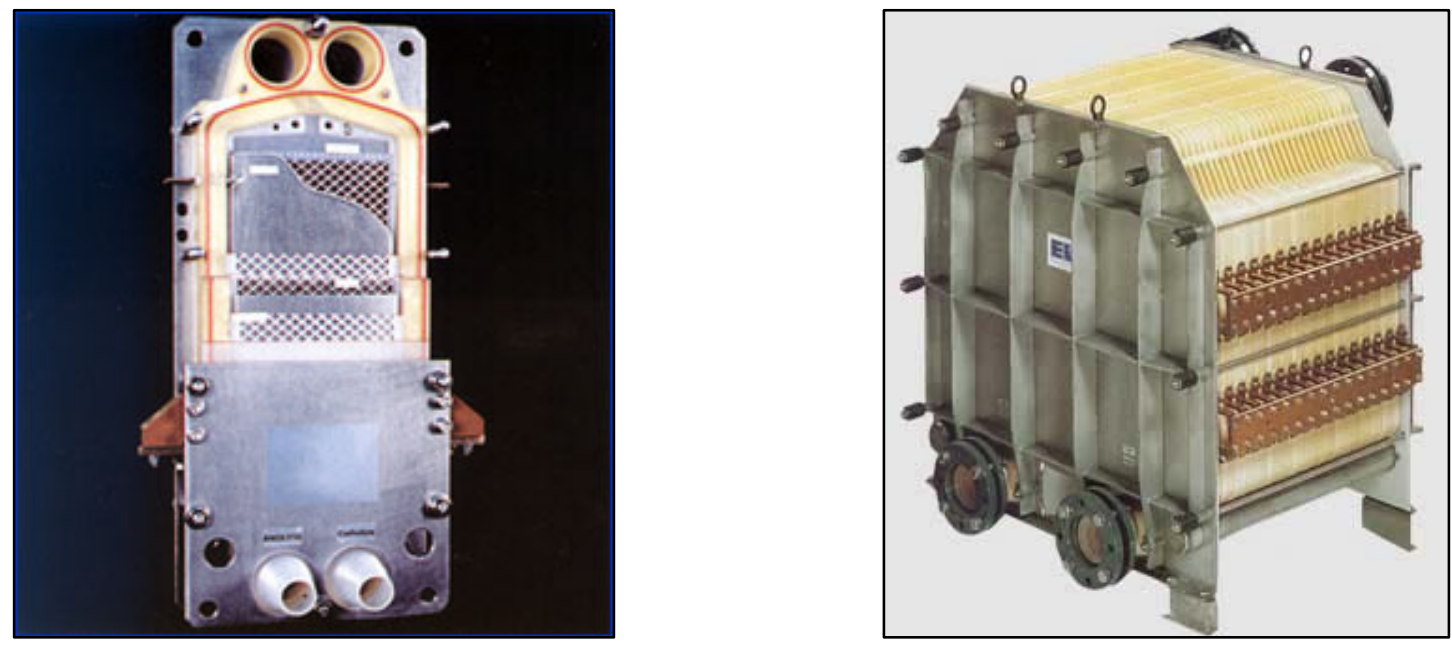

Figure 4.3. Laboratory and Pilot Scale Electrochemical Reactor Modules

The LAW feed stream is recirculated from the EC LAW Feed Tank through the anolyte chamber where sodium ions are transferred to the catholyte chamber. The membrane is manufactured to only allow $\mathrm{Na}^{+}$ transport, and other positive ions remain in the anolyte chamber. To maintain the charge balance, water is split at the anode releasing $\mathrm{H}^{+}$and oxygen. Other oxidation reactions will also occur in the anolyte. The primary reaction is the conversion of the large nitrite concentrations to nitrates. In the catholyte chamber, hydroxide ions are formed along with hydrogen gas. The transferred $\mathrm{Na}^{+}$is combined with hydroxide in the catholyte to produce a more concentrated $\mathrm{NaOH}$ solution. The $\mathrm{NaOH}$ solution is recirculated through the catholyte chamber and the Electrochemical Product Tank system. A low voltage $(<10 \mathrm{~V}) \mathrm{DC}$ power supply is used to force the transfer and maintain the charge balance. The power supply is a constant current system with the voltage that will vary between 2.5 and 10 volts. The power supplies will be supplied by three-phase alternating current with at least $480 \mathrm{~V}$ for a total power use of approximately 1 MW.

The cell design is based on recommendations in previous reports (Kurath et al. 1997a). The ECR scaffolds should be fabricated from polypropylene or polyether-ether-ketone (PEEK) with ethylenepropylene-diene monomer (EPDM) gasket material. The electrodes should be platinized titanium so current can be reversed for cleaning. Maintenance of the ECR modules would be performed in a containment structure in the airlock area. Before maintenance, the remaining solutions in the cells would be flushed back to the Receipt Tank for reprocessing.

An alternate cell arrangement could be considered to minimize connections or operate the cells in a bipolar mode to reduce the cost of electrical equipment or operations. One alternate cell design by Uhde has individual sealed cells of a larger size $\left(\sim 2 \mathrm{~m}^{2}\right)$ that could improve the reliability of the cell seals, allow bipolar operation, and possibly simplify change-out. However, every cell has separate cell connections via polymer tubing, increasing the number of connections over the current design concept. Simple quickdisconnect connection with zero leakage when disconnecting would be used during change-out. This type of cell has some advantages and warrants further review during a conceptual design phase. 
Another more advanced enhancement would to include depolarized porous cathodes to reduce hydrogen generation and electrical requirements (Saiki 1999). This design enhancement was not included because of the lack of operating experience, and the design has not been tested under conditions required for LAW treatment.

\subsubsection{EC LAW Feed Tank and EC Caustic Tank}

The feed tanks will consist of a two stainless-steel tanks for each function with capacities of $2000 \mathrm{~L}$ each. The tanks support the two banks of cells to provide redundancy in operations if one module has to be repaired. The recirculation system is operated at temperatures between 20 and $60^{\circ} \mathrm{C}$. The tanks will be fabricated from 304L SS. The tank will be relatively short to minimize pressure on the ECR, and the tanks will be located within the contaminated part of the facility. The tanks may also be located in a pit to provide some shielding from the main area.

Make-up water or dilute $\mathrm{NaOH}$ is provided to the EC caustic tank via the return line to maintain the level in the tank and prevent the $\mathrm{NaOH}$ concentration from increasing beyond 19M. LAW is provided to the EC LAW Feed Tank to maintain the level and to prevent the Al concentration from exceeding planned operational limits. The tank contents or outlet streams are monitored for level, specific gravity, radioactivity, and temperature.

\subsubsection{NaOH Product Tank}

The $\mathrm{NaOH}$ Product Tank involves the temporary storage of concentrated $\mathrm{NaOH}$ to allow for interruptions in the WTP's capability to receive the material into the pretreatment facility chemical make-up room. There are three $\mathrm{NaOH}$ product tanks with a capacity of $2000 \mathrm{~L}$ each. The tanks will be fabricated from 304L SS. Three tanks are used and sized to provide a combined 12 hours of product production before a transfer is required and to allow for analytical results from the tanks before transfer to the WTP pretreatment building. The transfer pump from the $\mathrm{NaOH}$ tanks will be capable of transferring $100 \mathrm{~L} / \mathrm{min}$ of $19 \mathrm{M} \mathrm{NaOH}$ to the WTP chemical make-up room.

An alternative to the product tanks is tote bins or tanker cars that could be transferred to the WTP building manually. A tote bin is expected to fill rapidly at approximately two per shift. A larger trucktanker trailer would take a couple of days to fill at nominal production rates.

The $\mathrm{NaOH}$ product tank control will be based on the Na concentration in the return stream from the ECR. If the Na concentration is too low in the return stream, the rate of product delivery will be decreased or stopped to allow the Na concentration to increase. If the Na concentration is too high, the rate of product delivered will be increased, and similarly, the rate of water addition will also be increased to reduce the Na concentration.

\subsubsection{EC Return Tank}

The treated LAW will be returned to the WTP from the EC return tanks. There will be two tanks with a 12-hour combined capacity of 60,000 L. An on-line Raman spectroscopy system will monitor the Na and Al concentrations to provide control of system operations. 


\subsubsection{Materials Compatibility}

Vessels, transfer lines, and system equipment will be manufactured from 300 series SS or an elastomer material capable of operating in $\mathrm{NaOH}$ concentrations up to $19 \mathrm{M}$ and $90^{\circ} \mathrm{C}$.

\subsubsection{Electrical Supply System}

The electrical supply for the building will be provided by the WTP substation used for the LAW vitrification plant. It is assumed the sufficient power is available. If additional power is required, a review of power supplies in the area would be required.

\subsubsection{Cooling Water System}

Cooling water is required for the electrochemical process feed tanks, the electrical supply equipment, condensers on the process tanks, and the process area. A cooling tower located outside the building provides the primary cooling to a heat exchanger inside the building with a capacity to remove $>500 \mathrm{~kW}$. A couple of cooling towers, as shown in Appendix D, could supply the needed cooling. The cooling tower would be approximately $20 \mathrm{ft}$ long by $12 \mathrm{ft}$ wide and $10 \mathrm{ft}$ tall. Secondary pumping systems will recirculate water to the appropriate process areas. The secondary systems will operate with water supplied to the process tanks at $<100^{\circ} \mathrm{F}$ and typical returns of $115^{\circ} \mathrm{F}$. The water to the condensers should be less than $85^{\circ} \mathrm{F}$, and the outlets should be used for the process tanks.

\subsubsection{Process Ventilation System}

The process ventilation includes an air inlet at the feed tanks to dilute process gases, notably hydrogen. The dilution gas required to maintain the hydrogen concentration below $1 \%$ is estimated to be $3200 \mathrm{scfm}$ per caustic feed tank. The exhaust from the tank would pass through a condenser and demister, allowing the water to drain back to the process tanks to minimize the loss of water and prevent water from condensing in the downstream building ventilation, including the high efficiency particulate air (HEPA) filters.

\subsubsection{Building Safety and Structural Systems}

The Building Safety and Structural Systems shall meet the same requirements as the WTP LAW Vitrification Building.

\subsubsection{Building Heating and Ventilation}

The Caustic Recycle Facility shall be provided with heating and ventilation. The ventilation shall flow from the office area to the area outside the main process area to the processing area and into the Zone 2 ventilation ducts with the process ventilation. The offices and control room will be controlled to ASHRAE requirements for continuously occupied spaces, but the main process area shall operate at elevated temperatures with limited personnel use.

\subsubsection{Water and Miscellaneous Utilities}

Process water and other utilities shall be supplied from the same source as the WTP facilities. A review of the availability and the needs of the Caustic Recycle Facility is required during the conceptual design. 


\subsubsection{Process Control System}

A central process control system will used to control all the process equipment from a central control room. Equipment shall be compatible to WTP equipment for ease of communications and storage of spare parts. Process control equipment shall be located outside the main process area as much as possible for ease of maintenance. Only primary sensors and wiring should be in the process areas.

\subsubsection{Physical Location and Layout}

The NaOH facility would be positioned near the WTP Building to use the north pipe trench connections and the substation power system. The exact location has not been determined. Possible locations include the area reserved for the second LAW Vitrification Building, the empty canister storage area to the east of the HLW Vitrification building, or the area west of the pretreatment building.

\subsubsection{Principles of Operation (Kurath et al. 1997b)}

The electrochemical salt-splitting process is based on inorganic ceramic membranes (as shown in Figure B.1 in Appendix B). In this process, the waste is added to the anode compartment, and an electrical potential is applied to the cell. This drives $\mathrm{Na}^{+}$ions through the membrane, but the ceramic membranes are selective, and most other cations (e.g., $\mathrm{K}^{+}, \mathrm{Cs}^{+}$) and anions are rejected. The charge balance in the anode compartment is maintained by generating $\mathrm{H}^{+}$from the electrolysis of water. The charge balance in the cathode is maintained by generating $\mathrm{OH}^{-}$, either from the electrolysis of water or from oxygen and water using an oxygen cathode. Other reactions, such as converting nitrites to nitrates, will also occur. The normal gaseous products of the electrolysis of water are oxygen at the anode and hydrogen at the cathode. Potentially flammable gas mixtures can be prevented by providing adequate volumes of a sweep gas or destroying the hydrogen as it is generated. As $\mathrm{H}^{+}$is generated in the anode compartment, the $\mathrm{pH}$ drops. The cathode compartment produces $\mathrm{OH}^{-}$that results in a rise in $\mathrm{pH}$ as the $\mathrm{Na}$ hydroxide product is recovered.

The NaSICON ceramics are polycrystalline materials that possess channels within the crystal structure for $\mathrm{Na}$ ion conduction. Silica tetrahedral rings, $\mathrm{Na}$, and heavy metal ions form the structure around these channels, which are filled with highly mobile Na ions. The channel size is determined by rare-earth ions. These materials are uni-dimensional ionic conductors, so the grain orientation affects the ionic transport rates. The new NaSICON materials are three-dimensional ionic conductors.

The ceramics act as Na-selective membranes by sterically blocking the passage of most competing ions. Monovalent cations that exhibit some conductivity in these materials are hydronium, $\mathrm{K}^{+}$, and $\mathrm{Ag}^{+}$. Larger monovalent cations, such as Cs, tend to be excluded from the crystal lattice by size, although there is some evidence for the transport of small amounts of cesium. Multivalent ions are excluded by electroneutrality requirements and in some cases by steric effects.

Ceramic membranes have superior resistance to fouling due to the tendency to exclude di- and tri-valent cations that can precipitate in organic membranes during salt splitting. Ceramic membranes also appear to have a high selectivity for Na relative to most other waste components. This is especially important in treating radioactive wastes where it is desirable to minimize the radioactivity in the recycled Na. 


\subsubsection{System Reliability Features}

Duplicate EC systems and low-maintenance pumps and valves are the primary reliability features. Pulsation dampeners or accumulator tanks may be used on the recirculation lines to dampen pressure fluctuations and assist in controlling the pressure differential across the membranes.

A process cooling water system is needed to maintain the temperature in the process from reaching excessive levels. Two recirculation pumps will be used for each process loop. The cooling tower will have multiple fans and excess capacity to provide reliable operation.

The electrical supply system to the building shall have back-up power for the process and building ventilation blowers as well as the process control systems. If normal power is lost, the process system will be shut down and the recirculation pumps stopped.

A process ventilation system will be provided for back-up power and automatic interlocks to the power supply. If the process ventilation is lost, the power to the electrochemical process will be turned off.

The building ventilation system requires two blowers for normal flow, and a third blower is available as a backup.

\subsection{Operations}

This section contains a description of the general operational requirements for performing the Na recycle system and has a general discussion of system startup, normal, off-normal, and shutdown operations.

\subsubsection{Initial Configuration}

Initially, the system will be assumed to be empty except that the Feed Receipt Tank is filled with LAW, and the EC caustic tank is full of dilute $\mathrm{NaOH}$. All other tanks, EC cells, and piping will be empty. All valves will be closed.

\subsubsection{System Startup}

\subsubsection{Fill EFT with LAW}

System startup will begin by activating P1 to fill the EFT with about 1800 liters of feed. Then P1 is turned off.

\subsubsection{Fill ECR with LAW}

Pumps P4 and P6 are turned on, and the appropriate valves are opened to allow low flow rates to fill the lines and EC cells without creating large pressure differentials. When the tank levels stabilize, the flow rates on P1 and P6 are gradually increased to operating levels of $3200 \mathrm{~L} / \mathrm{min}$. All instrumentation will be checked for proper operation.

\subsubsection{Refill EFT and ECT}

Pump P1 is activated to fill the EFT to the proper operating level, and then the system is switched to automatic control to maintain the tank at preset hydroxide values. The ECT tank is filled with water and 
switched to automatic control to maintain the concentration in the tank at $19 \mathrm{M} \mathrm{NaOH}$. The automatic valve remains closed until the $\mathrm{NaOH}$ concentration reaches $19 \mathrm{M}$ and slowly opens to allow the solution to transfer to the buffer tanks. When the level in the tank drops, the control valve on the water lines opens to maintain the operating level in the tank.

\subsubsection{Turn Power on to ECR}

Power is then supplied to the ECRs to start transferring sodium. The current is gradually increased while the instrumentation on the fluid return streams are monitored for temperature, flowrate, density, $\mathrm{Na}$ concentration. The NaOH stream is also monitored for radioactivity. The LAW stream is also monitored for hydroxide concentration in stream. When the aluminate and hydroxide levels for the LAW reach the appropriate value, the valve to the ERT is opened and the flow rate controlled to maintain the hydroxide level between preset values. Later, the $\mathrm{NaOH}$ concentration will reach $19 \mathrm{M}$, and the valve to the NPT will be opened. The temperature of the system will increase during operation, and when it reaches $40^{\circ} \mathrm{C}$, the cooling system will be turned on to maintain the specified temperature.

\subsubsection{Normal Operations}

The P1 pump will maintain the concentrations and levels in the EFT while the water inlet valve will maintain the level and $\mathrm{NaOH}$ concentrations in the ECT. The product streams transfer will be controlled based on the concentration of the appropriate cation $\mathrm{Na}$ and hydroxide to maintain the values within a fixed operating range. The EC receipt tank would be refilled from WTP tanks as needed based on verbal requests and interlocks between facilities to prevent overfilling. The acquisition/control system will continually acquire data and automatically control operations.

\subsubsection{Off-Normal Operations (System Upsets)}

In the event of an off-normal scenario, the following steps will be immediately performed in the specified order:

1. Stop all pumps

2. Stop cooling system

3. Turn off ECR power.

\subsubsection{System Shutdown}

\subsubsection{Turn off Electrical Power to ECRs.}

When system is operating, shutdown will start by turning off the power to the ECRs while the process pumps continue to operate. The flow to the ECRs is shutdown as described below:

1. Stop pumps for recirculation loops and allow automatic pressure control system to maintain equal pressure in the EC cells while they drain to the feed tanks.

2. Stop cooling water systems

3. Rinse process system

4. Return to initial configuration 


\subsection{References}

Kirkbride RA, GK Allen, PJ Certa, TW Crawford, and PG Haigh. 2007. Tank Farm Contractor Operation and Utilization Plan. HNF-SD-WM-SP-012 Revision 6, CH2M HILL Hanford Group, Inc., Richland, Washington.

Kurath DE, KP Brooks, GW Hollenberg, R Clemmer, S Balagopal, T Landro, and DP Sutija. 1997a. Preconceptual Design of the Salt Splitting Process Using Ceramic Membranes. PNNL-11454, Pacific Northwest National Laboratory, Richland, Washington.

Kurath DE, GW Hollenberg, J Jue, J Smith, AV Virkar, S Balagopal, and V Sutija. 1997b. "Salt Splitting using Ceramic Membranes.” Sep. Sci. Tech. 32:557-572.

Poloski AP, DE Kurath, LK Holton, G Sevigny, and M Fountain. 2008. Economic Feasibility of Electrochemical Caustic Recycling at the Hanford Site. In press, Pacific Northwest National Laboratory, Richland, Washington.

Saiki K, A Sakata, H Aikawa, and N Furuya. 1999. "Reduction of Power Consumption of Chlor-alkali Membrane Cell.” In: Electrochemical Society Proceedings 99-21.

Bryan, SA, Tatiana Levitskaia, Steve Schlahta, 2008. Raman Based Process Monitor for Continuous Real-Time Analysis of High Level Radioactive Waste Components, WM2008 Conference, Phoenix, AZ 


\subsection{Bibliography}

Fiskum SK, ST Arm, WC Buchmiller, T Trang-Le, JE Martinez, J Matyas, MJ Steele, KK Thomas, and DL Blanchard, Jr. 2006. Comparison Testing of Multiple Spherical Resorcinal-Formaldehyde Resins for the River Protection Project- Waste Treatment Plant. PNWD-3785, WTP-RPT-143, Rev 1, Pacific Northwest National Laboratory, Richland, Washington.

Kurath DE, KP Brooks, GW Hollenberg (PNNL), DP Sutija, T Landro, and S Balagopal (Ceramatec). 1997c. "Caustic Recycle from High-salt Nuclear Wastes Using a Ceramic membrane Salt-splitting process.” Separation and Purification Technology 11:185-198.

Kurath DE, KP Brooks, GW Hollenberg, WE Lawrence, and S Balagopal. 1998. Development and Testing of a Ceramic Membrane Based Salt Splitting Process for Caustic Recycle. Pacific Northwest National Laboratory, Richland Washington, Ceramatec Inc., Salt Lake City, Utah.

Perez JM, Jr., DK Peeler, DF Bickford, DM Strachan, DE Day, MB Triplett, DS Kim, JD Vienna, SL Lambert, RS Wittman, and SL Marra. 2001. High-Level Waste Melter Study Report. PNNL-13582, Pacific Northwest National Laboratory, Richland, Washington. 


\section{Appendix A: Cost Study Summary}

The cost benefit for caustic recycling is assumed to consist of four major contributions: 1 ) the cost savings due to avoiding the production of additional immobilized low-activity waste (ILAW) glass, 2) caustic-recycle capital investment, 3) caustic-recycle operating and maintenance costs, and 4) research and technology (R\&T) costs needed to deploy the technology. In estimating costs for each of these components, several parameters are used as inputs. Due to uncertainty in assuming a singular value for each of these parameters, a range of possible values is assumed. A Monte Carlo simulation is then performed where the range of these parameters is exercised, and the resulting range of cost benefits is determined.

The major conclusions from the Monte Carlo model results discussed in this report are summarized below:

- A feasible region for minimal plant economics (e.g., 10\% return on investment) corresponds to approximately 10,000 MT sodium recycled. Return on investments in the range of 30 to $60 \%$ can be achieved when 50,000 MT of sodium are recycled.

- Literature data for the growth rate of Gibbsite particles indicate that particles forming in the 1- to 10-micron range over the average vessel residence time of 1 week corresponds to a saturation ratio less than eight. The operation of the downstream WTP processes under these conditions and with particles of this size must be demonstrated in a separate experimental program.

- Recycling 10,000 MT of sodium results in a cost savings in ILAW glass of \$0.7B to \$1.0B. If 30,000 MT of sodium is recycled, $\$ 2.5 \mathrm{~B}$ to $\$ 3.1 \mathrm{~B}$ would likely be realized.

- Recycling 10,000 MT of sodium results in an estimated range of total capital cost for the causticrecycle facility to be $\$ 175 \mathrm{M}$ to $\$ 325 \mathrm{M}$. If $30,000 \mathrm{MT}$ of sodium is recycled, $\$ 200 \mathrm{M}$ to $\$ 350 \mathrm{M}$ would likely be realized.

- An improved cost benefit analysis for caustic recycle facilities should focus on improving the basis for the following questions (listed in priority):How much sodium will be added for caustic leaching?

o What level of supersaturation can be tolerated?

o What is the cost savings from preventing additional ILAW glass production?

0 What are the total capital costs for the caustic-recycle facility?

o What are the operating and maintenance costs for the caustic-recycle facility? 


\section{Appendix B: System Sketches, Equipment List, and Electrical Loads}

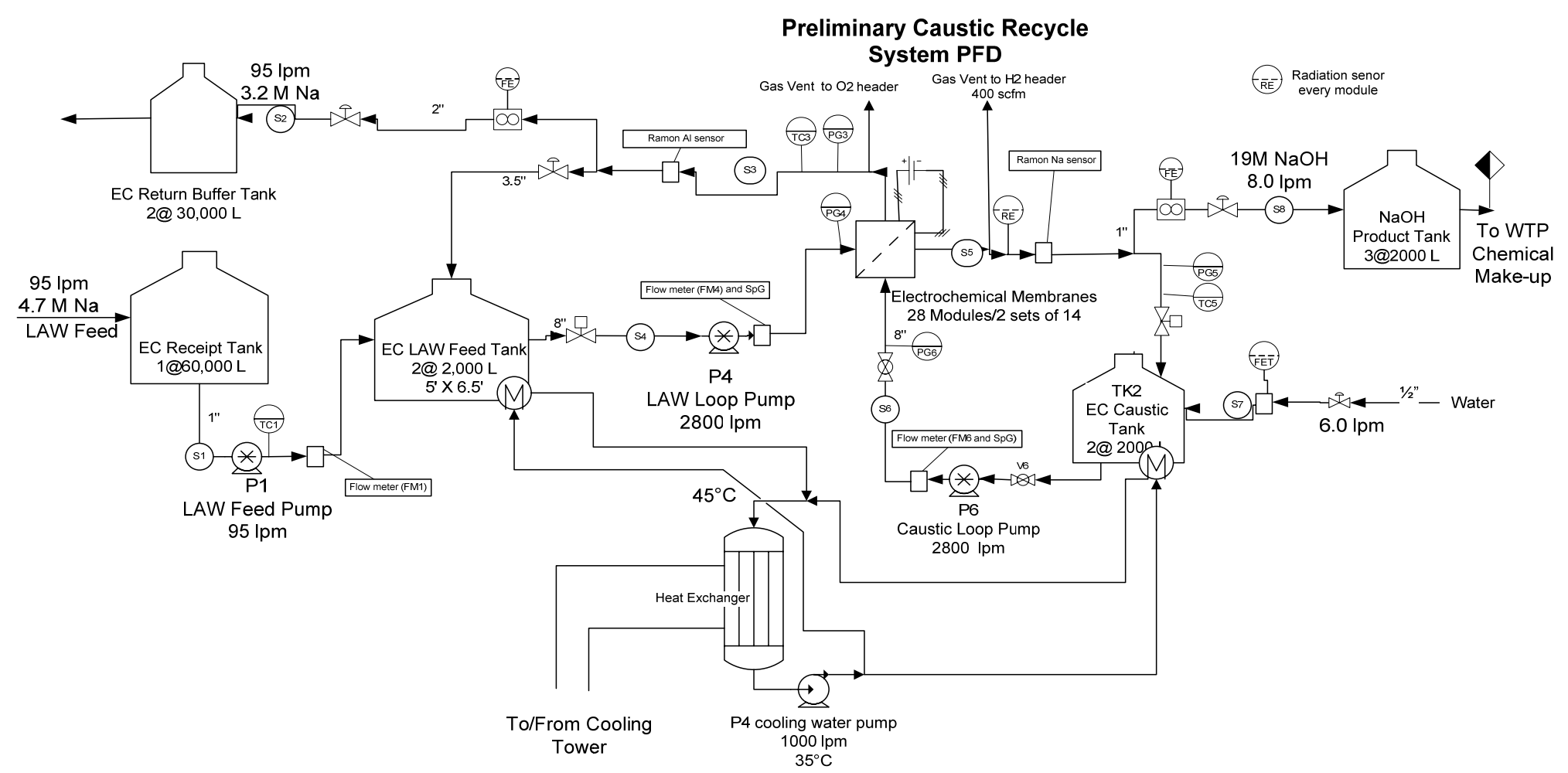

Revision B, 8/28/07

Figure B.1. Na Recycle Plant Flow Diagram 


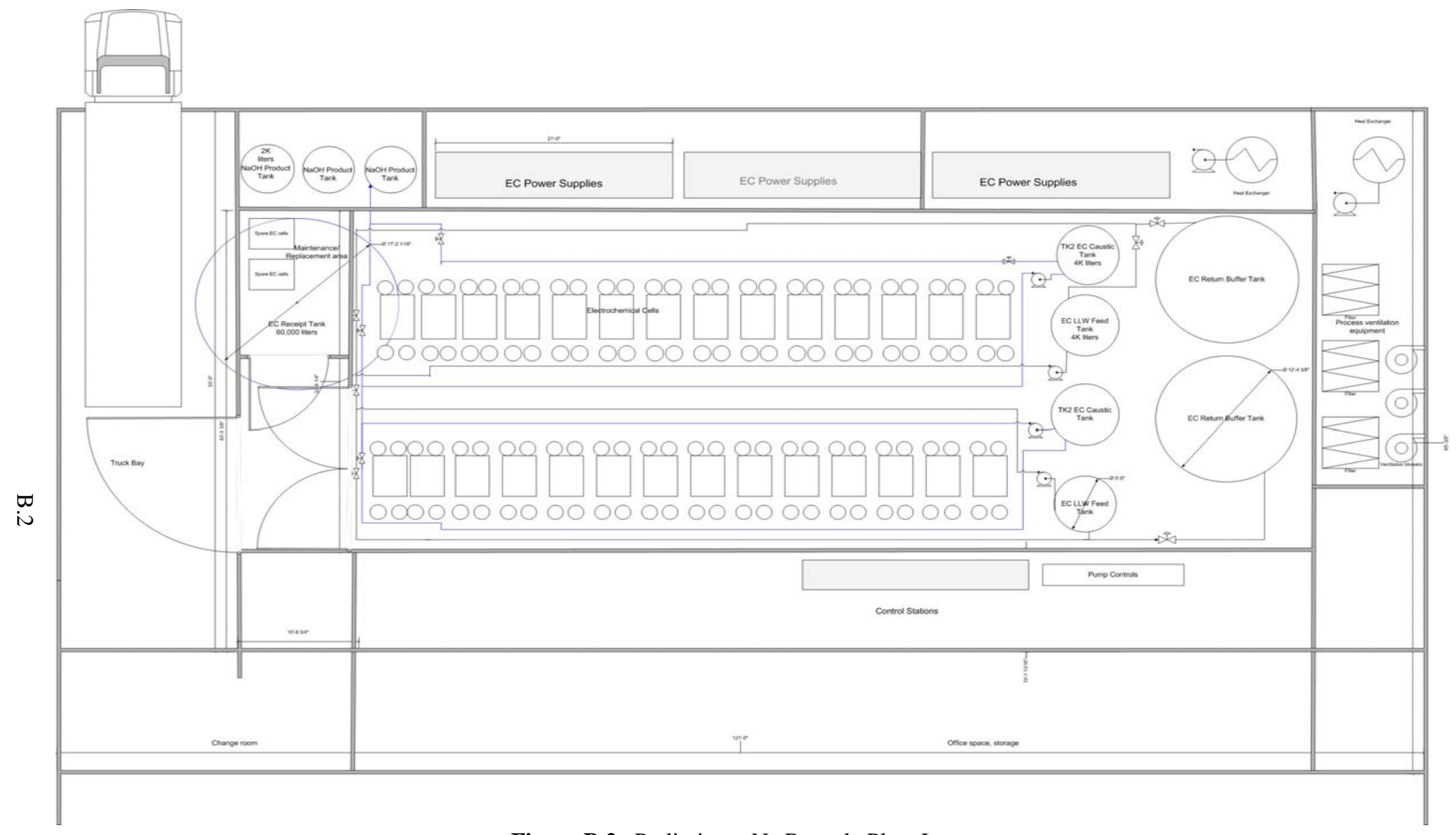

Figure B.2. Preliminary Na Recycle Plant Layout 


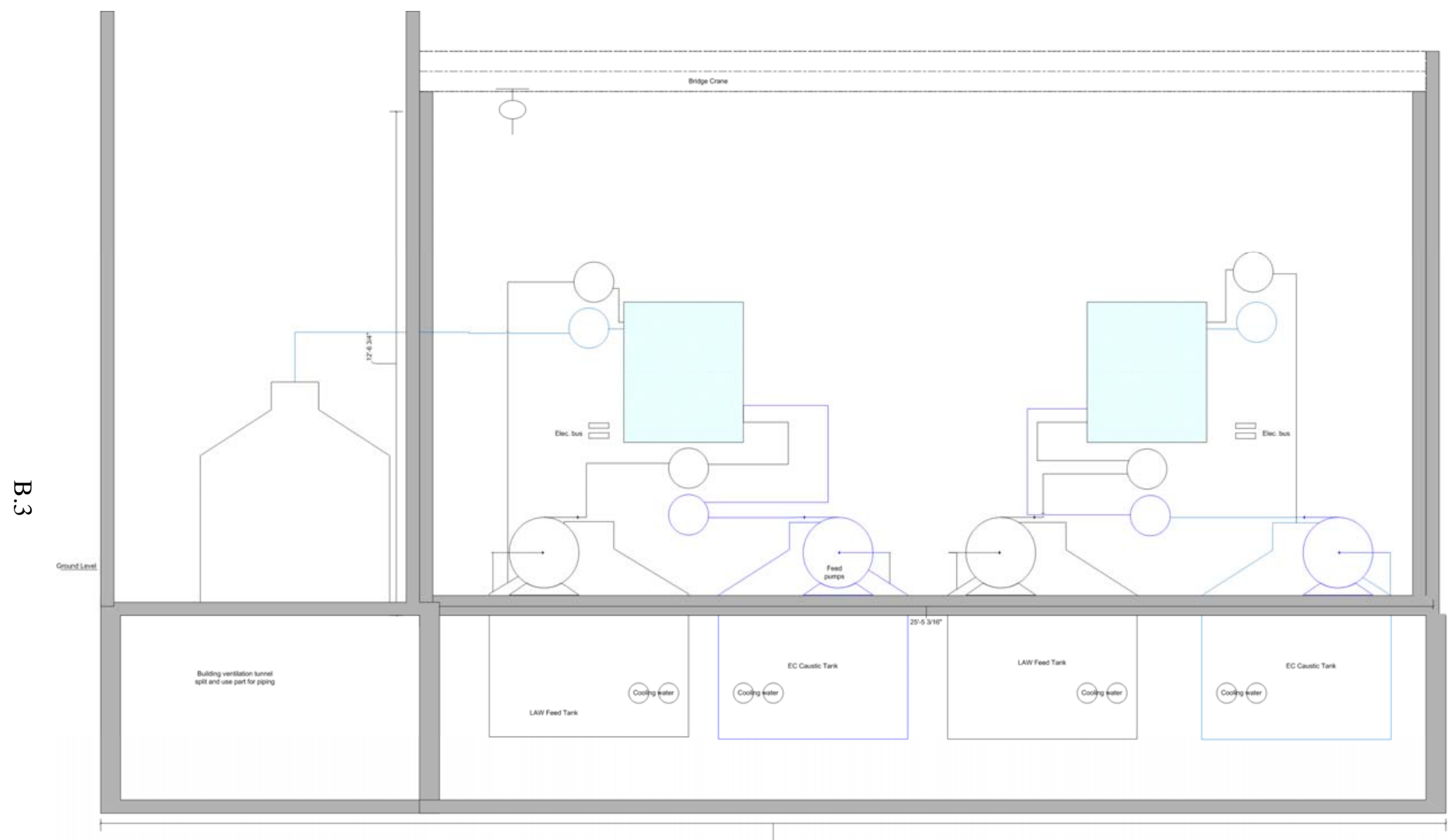

Figure B.3. Plant Elevation 
Table B.1. Major Equipment List

\section{Caustic Recycle System Equipment List}

\section{EQUIPMENT NAME}

EC Return Buffer Tank

EC Receipt Tank

EC LAW Feed Tank

EC Caustic Tank

$\mathrm{NaOH}$ Product Tank

EC Return Buffer Agitator

EC LAW Feed Agitator

Electrochemical Modules

ECR heat exchanger

LAW feed pump

Caustic Loop Pump

$\underset{\perp}{+\infty}$

LAW Loop Pump

LAW return pump

$\mathrm{NaOH}$ to WTP pump

Cooling Water Pump

Ventilation Blowers

LAW to ECC loop

flowmeters

$\mathrm{NaOH}$ flowmeters

Cooling Tower Pump

Process Area Bridge Crane

Truck Bay Bridge Crane

AC/DC power Supplies

Ventilation Filters

airlock doors

crane doors

\section{DESCRIPTION}

30,000 liter SS closed tank with agitator $12 \mathrm{ft}$ dia. by $12 \mathrm{ft}$ tall

60,000 liter SS tank, no agitator, $17 \mathrm{ft}$ dia. by $10 \mathrm{ft}$ tall

2,000 liter SS tank with cooling coils, $5 \mathrm{ft}$ dia. by $6.5 \mathrm{ft}$ tall

2,000 liter SS tank with cooling coils, $5 \mathrm{ft}$ dia. by $6.5 \mathrm{ft}$ tall

2,000 liter SS tank, $5 \mathrm{ft}$ dia. by $6.5 \mathrm{ft}$ tall

Mechanical agitator for EC return tank, off the bottom agitation requirement

Mechanical agitator for EC Feed tank

ElectroProd Module with 40 ceramic scaffolds each

$400 \mathrm{MW}$ heat removal capacity with minimum $10^{\circ} \mathrm{C}$ temperature difference

50 to $200 \mathrm{~L} / \mathrm{min}$ variable flow centrifugal pump 30 psig outlet

2000 to $4000 \mathrm{~L} / \mathrm{min}$ variable flow rate low head

2000 to $4000 \mathrm{~L} / \mathrm{min}$ variable flow rate low head

$500 \mathrm{~L} / \mathrm{min} 60 \mathrm{psig}$

nominal $100 \mathrm{~L} / \mathrm{min}$ flow rate 3

300 to $400 \mathrm{~L} / \mathrm{min}$ flow rate, 30 to 50 psig 2

$60,000 \mathrm{cfm}$

500 to $5000 \mathrm{~L} / \mathrm{min}$

500 to $5000 \mathrm{~L} / \mathrm{min}$

$1000 \mathrm{~L} / \mathrm{min} 60$ psig centrifugal pump 3

10 tons capacity 1

20 tons capacity 1

1MW DC power supply with variable voltage of 1 to $6 \mathrm{~V}$ outlet, 3 phase $480 \mathrm{~V}$ power input.

HEPA filters 60,000 CFM
Quantity Size

3

30000 liters

60000 liters

2000 liters

2000 liters

2000 liters

$8.8 \mathrm{~m} 2 /$ module 
Table B.2. Major Electrical Loads

\begin{tabular}{cc} 
Number & Equipment Name \\
& \\
1 & LAW feed pump \\
2 & Caustic Loop Pump \\
2 & LAW Loop Pump \\
2 & LAW return pump \\
3 & NaOH to WTP pump \\
2 & Cooling Water Pump \\
4 & Cooling Tower Fans \\
2 & EC Return Buffer Tank Agitator \\
2 & EC LAW Feed Tank Agitator \\
3 & Ventilation Blowers - SP 6 in. \\
& Instrumentation \\
2 & Cooling Tower Water Pump \\
\hline & B ridge Cranes \\
1 & AC/DC power Supplies for ECR \\
& Building Heating and Cooling - \\
& estimate
\end{tabular}

\begin{tabular}{|c|c|c|c|c|c|}
\hline \multirow[b]{2}{*}{$\begin{array}{c}\text { Nominal HP } \\
\text { each }\end{array}$} & \multirow[b]{2}{*}{ Motor RPM } & \multirow[b]{2}{*}{$\begin{array}{c}\text { BRAKE } \\
\text { HP or KVA } \\
\text { each }\end{array}$} & \multicolumn{3}{|c|}{ NORMAL } \\
\hline & & & $\begin{array}{c}\text { kW } \\
\text { OPERATING } \\
\text { total }\end{array}$ & PHASE / & OPERATION \\
\hline 0.5 & 1750 & 1 & 1 & 3 & continuous \\
\hline 3 & 850 & 5 & 7 & 3 & continuous \\
\hline 3 & 850 & 5 & 7 & 3 & continuous \\
\hline 1 & 1750 & 2 & 3 & 3 & intermittent \\
\hline 1 & 1750 & 2 & 4 & 3 & intermittent \\
\hline 2 & 1750 & 3 & 4 & 3 & continuous \\
\hline 5 & 1750 & 5 & 15 & 3 & continuous \\
\hline 25 & 1750 & 25 & 37 & 3 & continuous \\
\hline 5 & 1750 & 5 & 7 & 3 & continuous \\
\hline 65 & 1750 & 100 & 224 & 3 & continuous \\
\hline NA & NA & 1 & 1 & 1 & continuous \\
\hline 3 & 3600 & 5 & 7 & 3 & continuous \\
\hline 5 & 1750 & 5 & 7 & 3 & intermittent \\
\hline$N A$ & NA & 2000 & 1000 & DC & continuous \\
\hline & & & 200 & & \\
\hline & & Total & 1527 & & \\
\hline
\end{tabular}




\section{Appendix C: Technology Development Needs}

The NaSICON technology has been demonstrated with simulated low-activity waste with 3000 hours (verbal communication with Shekar Bologapal) of operation and with actual waste on small scale. Further development or demonstration of reliability, control, maintenance, and secondary waste generation is an area that is key to moving the technology from the laboratory to the field. Some recommendations have been made by an independent review group led by W.R. Wilmarth. ${ }^{(a)}$ The technology needs are as follows:

- Demonstrate mass production of large quantities of quality ceramic membranes with reliable performance and strength.

- Demonstrate operation of multiple full-scale cells for extended period.

- Measure all gas produced in cells to characterize the exhaust so the ventilation system can be designed.

- Demonstrate maintenance of cells in confined environment with prototypic connectors.

- Determine secondary waste generation rates and waste types.

- Further testing to underpin the stability of supersaturated aluminate solutions is needed.

- Insufficient data exist at high catholyte caustic levels (50 wt \%) to confirm NaSICON electrochemical cell operability and reliability at these conditions.

- Demonstrate on-line instrumentation for hydroxide and aluminate concentrations.

- Demonstrate reliability of electrodes, membranes, and other module components.

Other technology enhancements, including some mentioned in early reports (Kurath et al. 1997a), would reduce overall cost but are not required to implement the technology. These items include the following:

- Make improvements in membrane lifetime.

- Develop increases in sodium ion conductivity to reduce the size or operating cost for the facility.

- Develop an oxygen gas diffusion cathode or innocuous reductant chemical to eliminate hydrogen generation.

- Develop accurate monitoring and control plans to rapidly stop operations if a membrane is about to fail or has failed.

- Develop a reliable hydrogen depolarized electrode without polytetraflouroethylene to destroy hydrogen shortly after it is formed and reduce overall power requirements.

(a) WR Wilmarth, DT Hobbs, WA Averill, EB Fox, and RA Peterson. 2007. Review of Ceramatec's Caustic Recovery Technology. WSRC-STI-2007, Revision 0, Westinghouse Savannah River Company, Aiken, South Carolina. 


\section{Appendix D: Equipment Examples}

\section{Vertical Cantilevered Pump}

WIDE RANGE OF APPLICATIONS:

- Coal Fines and Slurry

- Waste Paper Stock

- Clay and Water

- Iron Ore Slurry

- Black Liquor

CAPABILITI ES:

- Capacities to 1600 GPM

- Heads to 170 Feet

- Temperature to $400 \mathrm{~d}$. F

- Pump Length to 6 Feet

CONSTRUCTION:

- 316 Stainless Steel Fitted

- Alloy 20

- Hastelloy

- $\mathrm{CD} 4 \mathrm{MCu}$
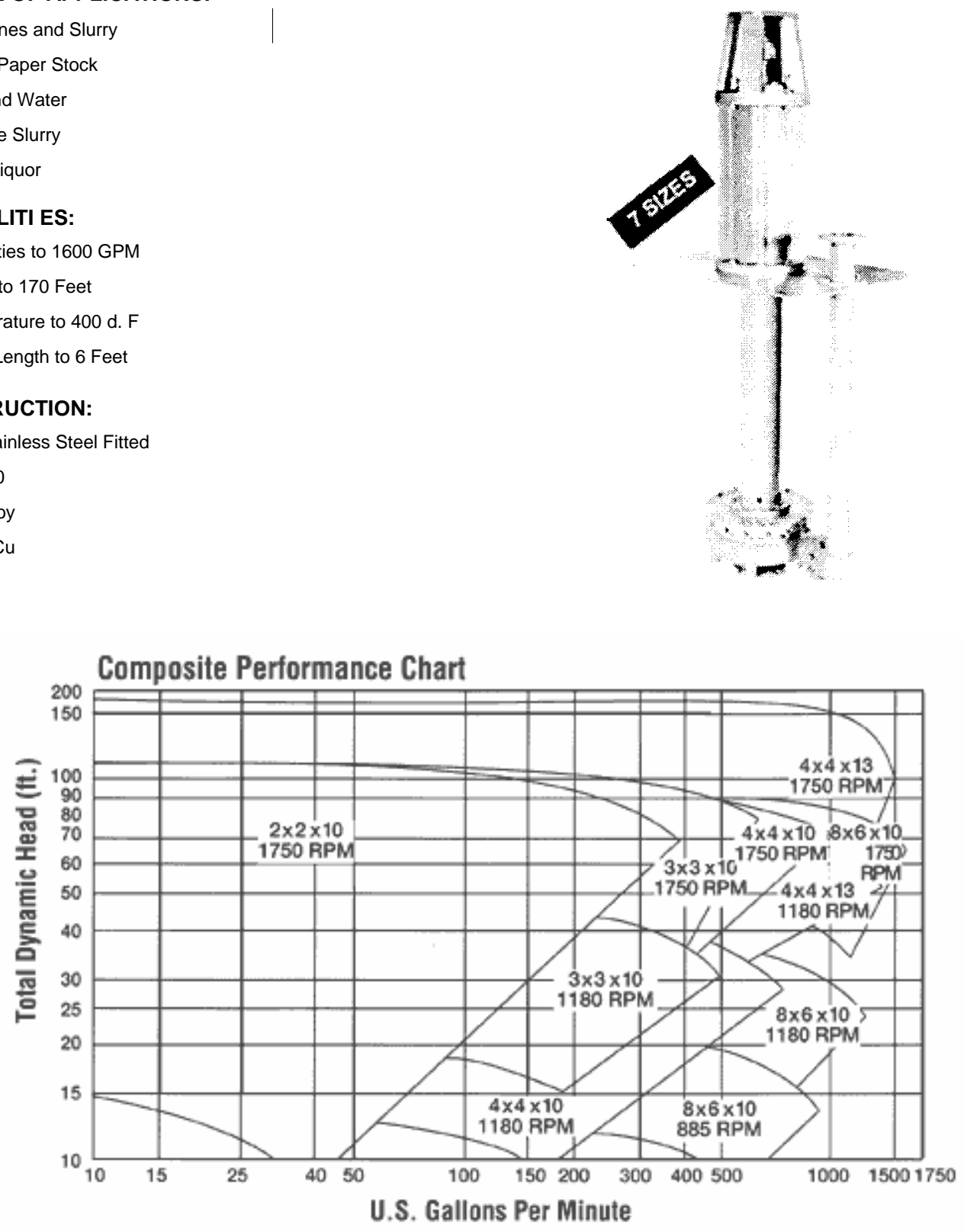

D.1 


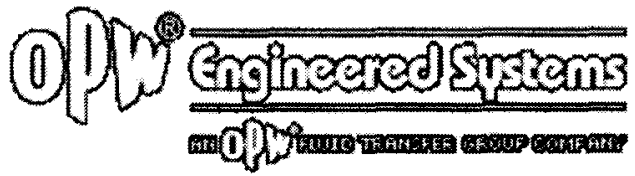

\section{Dry Disconnects/Dry Disconnect Couplers}

OPW offers the most complete line of dry disconnect products in the industry. The economical cam-and-groove coupler $\mathrm{Kamvalok}^{\circledR}, \mathrm{Epsilon}^{\mathrm{TM}}$, and. Drylok ${ }^{\mathrm{TM}}$ are suitable for a broad range of hazardous liquid transfer applications up to 3 inch diameter.

\section{Drylok $^{\mathrm{TM}}$}
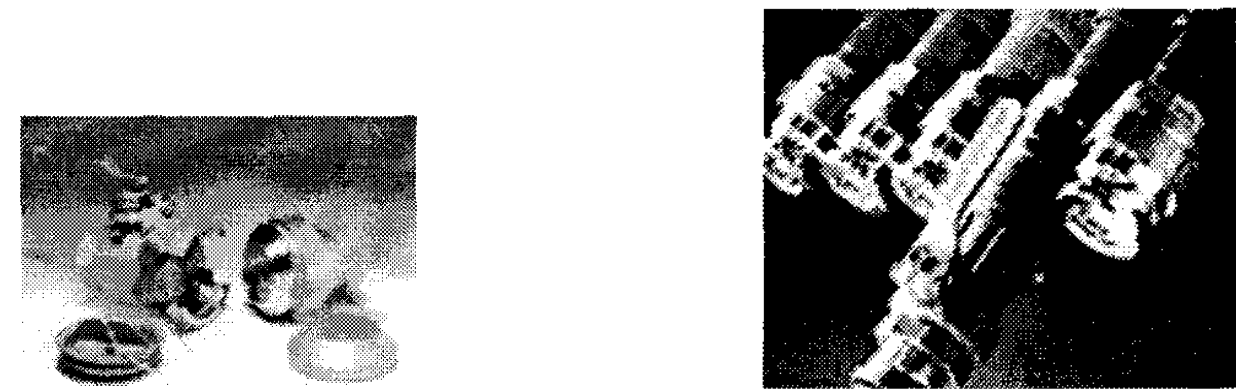

Drylok $^{\text {rm }}$

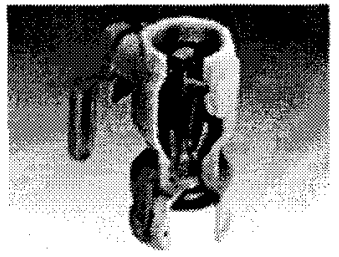

$\underline{\text { D2000 }}$ TM Actuator Series

\section{Kamvalok®}

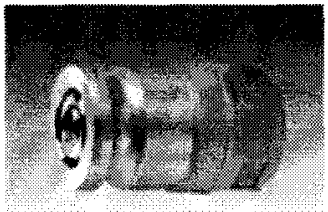

1600AN

Series A

Epsiion $^{\mathrm{TM}}$

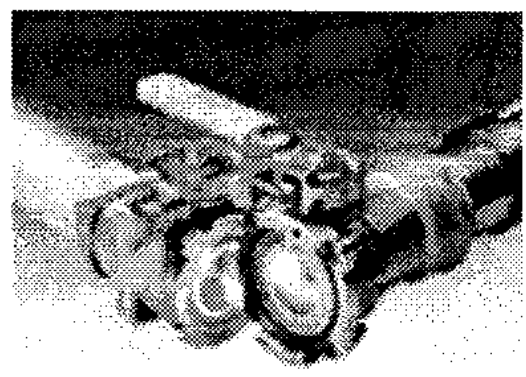




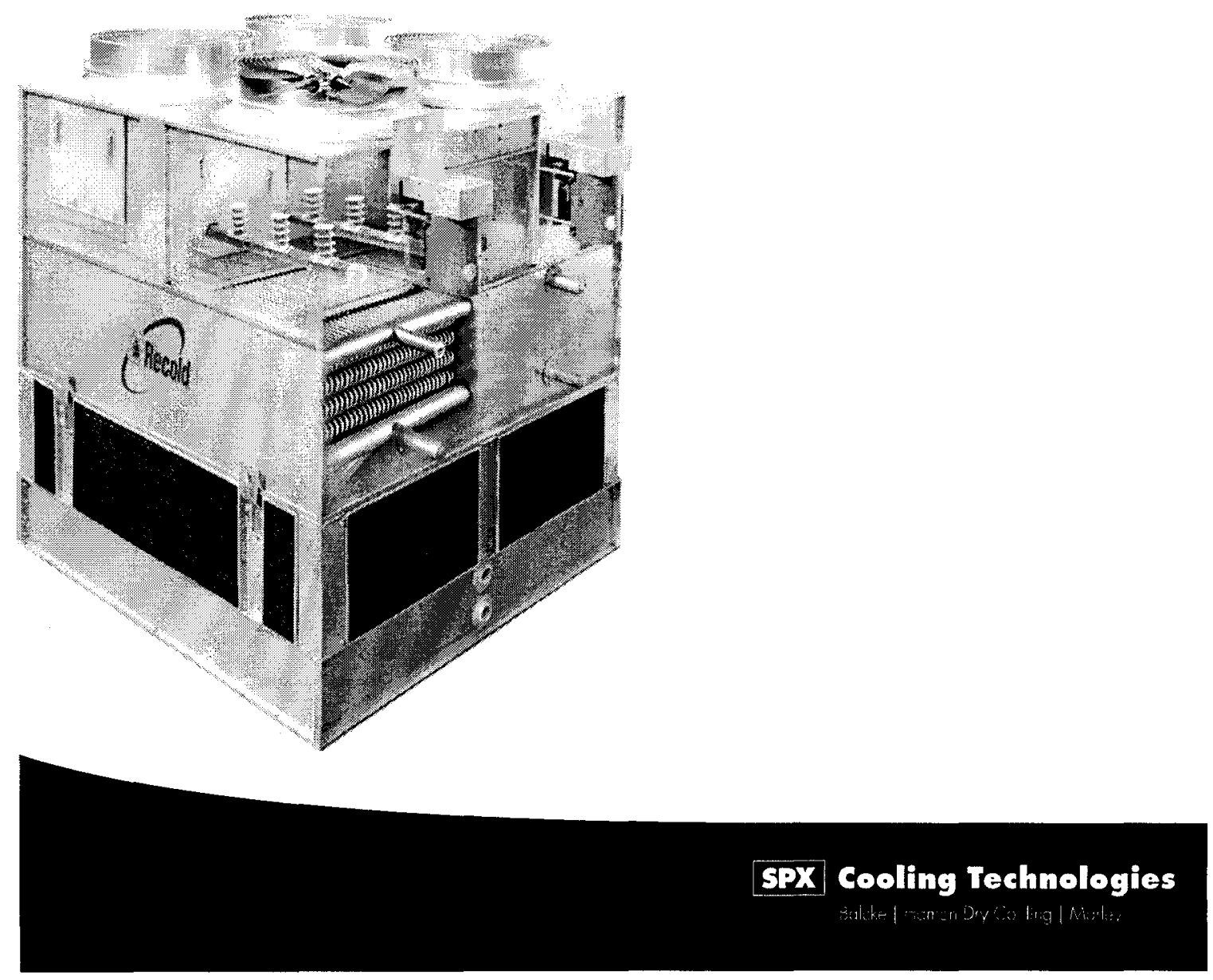

Typical Cooling Tower (Two required for Caustic Recycle Facility) 